\title{
Estimation of Productivity Growth in the Saudi Higher Education Sector
}

\author{
Yaseen Ghulam ${ }^{\mathrm{a}, \mathrm{b}}$ and Wael I. Mousa \\ a. Al Yamamah University 7010 King Fahd Road, \\ Al Qirawan, Riyadh 13541, Saudi Arabia \\ b. University of Portsmouth, Faculty of Business and Law, \\ Economics and Finance Subject Group \\ Richmond Building, Portland Street, PO1 3DE, UK \\ Email: yaseen.ghulam@port.ac.uk
}

Phone: +442392844127 


\title{
Estimation of Productivity Growth in the Saudi Higher Education Sector
}

\begin{abstract}
Studies on higher educational sector efficiencies and productivities based on newly developed nonparametric techniques such as $\alpha$-quantile estimator are not common compared to in other industries. By using an advanced non-parametric estimator to overcome dimension and outlier issues, we investigate the performance of Saudi Arabian higher education institutions during the period 2008 to 2014, a period characterized by a significant increase in the government educational budget and a push for the substitution of foreign labour with local under Saudization policy. We conclude that due to spending large sums of money on sponsoring $\mathrm{PhDs}$ from Western institutions for local young Saudis, exponential growth in investment in relation to creating and maintaining huge educational infrastructure and reforms that allowed the private sector to participate in the higher education market resulting in a significant increase in competition, productivity improved for both public and privately owned institutions due mainly to technological progress. The larger and older publicly owned influential institutions in particular played catch-up with a shift in frontier technology as well as achieving improvements in efficiency in producing graduates. We trace the significant technological progress during the sample period to better economic conditions leading to investment made in new learning technologies and human resource development. Rather disappointingly, though, an increase in Saudi females' participation in secondary/tertiary education and academic jobs, which is part of the country's new national economic and social policy known as Vision 2030, is negatively linked with technological progress for the larger publicly owned higher education institutions in particular.
\end{abstract}

JEL classification: C14; I23; J24

Keywords: education; productivity; $\alpha$-quantile estimator; Saudi Arabia; female labour market participation

Word count: 15357 


\section{Introduction}

Studies on efficiency and productivity estimation have been forthcoming for a long time. The industries that have been most widely researched in this regard include the manufacturing, financial, telecommunication and higher education sectors. But compared to other industries, the measurement of efficiency and productivity in higher education institutions (HEIs) has been relatively scarce. Important works that have been cited by a number of research papers include studies by authors such as Johnes (2008), and Athanassopoulos and Shale (1997) for the UK, Agasisti and Perez-Esparrells (2010) for Italy, Eckles (2010) for the USA, Kantabutra and Tang (2010) for Thailand, Wolszczak et al. (2011) for Austria, Cunha and Rocha (2012) for Portugal, and Stoica and Aldea (2016) for Romania. A survey, albeit rather old, on the efficiency and productivity of HEIs can be found in Worthington (2001) and Johnes (2004). For resource-rich Gulf Cooperation Council (GCC) countries that have been spending billions of dollars on education to make the local population on a par with expatriates and push universities toward being ranked in the top tier in the world, not a single well-cited and robust study exists. Studies by authors such as Al-Mutairi and Al-Shami (2015) for Saudi Arabia and Alshayea et al. (2013) for Iraq seriously lack any rigour and findings are, to a large extent, questionable.

This study fills this important gap in empirical literature and estimates efficiency and productivity in the Saudi Arabian higher education sector. The Kingdom of Saudi Arabia ('the Kingdom') is one of the most significant of the GCC countries with a population of 31 million and an emerging private sector. The country is blessed with an abundance of young people and there is an emerging higher education sector comprising public sector universities, private higher education institutions and specialist colleges such as vocational, medical and generic education provider institutions. Direct entry of foreign institutions is not

allowed but this may change soon after the adoption of Vision 2030, which stresses the importance of the private sector in diversifying the economy. In the following paragraphs, more context is provided in terms of why this country has been chosen as a case study for the analysis of productivity in higher education, justification of the preferred method to estimate productivity and how this study is different compared to the existing international empirical studies mentioned above, and finally the implication of the findings of this study for resource-rich economies following a similar Saudi path of promoting higher education by investing big money in human resources and the development of physical infrastructure alongside implementing policies in relation to the promotion of local employment and women's participation in higher education in particular and other countries in general.

Education in Saudi Arabia has been the top priority in setting the national budget. Alongside a number of private institutions, the Kingdom has a large network of 29 public sector universities with more than 133 
campuses, schools and colleges. These public sector institutions are well funded and quite influential in terms of providing breeding grounds for top government jobs. A significant number of the current array of ministers and advisors have been attached to prestigious public sector universities. For a number of years, a third of the national budget has been spent only on education. Government spending on education and training stood at around US \$53.9 billion in 2014, followed by about US\$ 55.5 billion in 2015 and US\$ 57.3 billion in 2016. This spending on education in terms of percentage of total budget outlay is higher than in many industrialized developed countries such as the UK, the United States, Germany, France and Japan (who spend around $10-15 \%$ of their total government spending). Hence, it is natural to ask whether there is any link between higher spending on education and efficient utilization of the resources on which this money is spent. Surprisingly, we know little about the productivity of the Saudi Arabian higher education sector, even less about the difference between giant public sector universities with more than 50,000 students enrolled in each institution and smaller newly established private institutions, and almost nothing about the role played by technology upgrades and the increasing level of competition in improving higher education productivity in the Kingdom. The findings of this study will shed some light on how the higher education sector in particular has responded to the phenomenal increase in financial and human resources from the government over time.

Saudization is a policy whereby expatriate workers are replaced with a local Saudi workforce. The policy has been active since 1980 but has become more regularly enforced since 2006. Lots of administrative staff and managers in different departments of both public and private universities such as human resources, finance and research centres have been going through a significant transformation in this regard to fully meet Saudization requirements. Local Saudi administrative staff have undergone regular training aimed at meeting international standards but still the work culture and efficiency are not on a par with these standards. Many Saudis who received generous scholarship opportunities abroad are back and employed as faculty members in Saudi universities (both public and private). These faculty members are knowledgeable but some say that they lack incentives to work hard because they receive immediate tenure in publicly owned universities without fulfilling preconditions in relation to teaching and/or research productivity.

Foreign faculty members who still hold a significant share do not get any tenure regardless of their performance in teaching and research. This has immediate implications for job security and the situation may get even worse as Saudization is implemented more widely under Vision 2030 to accommodate local Saudis in academic and administrative positions. Guaranteed tenure positions for Saudi academic staff and difficulty in firing local administrative staff coupled with eased labour market conditions and a more relaxed macroeconomic environment due to high oil prices, which makes searching for jobs less costly, 
may not help improve effort levels. On the other hand, the emerging threat of losing jobs due to substitution could force foreign academic and administrative staff to increase their effort level to avoid losing substantially higher wages compared to what they would be earning at home. Hence, it would be interesting to observe whether or not the Saudization policy has encouraged both local and foreign administrative and academic staff to become productive and efficient over time.

HEIs are expected to produce at least two outputs, namely teaching and research publications. Hence an estimator of efficiency and productivity should be able to accommodate multiple outputs. A regressionbased stochastic frontier approach is not a preferred method due to its inability to accommodate multiple outputs. In addition, strong assumptions about functional form are also subject to greater criticism in empirical and theoretical literature. Hence, a technique such as data envelopment analysis (DEA) in this case is best suited than the parametric stochastic frontier method due to its ability to accommodate multiple outputs and no a priori assumption of the functional form. A non-parametric method comprising DEA techniques to estimate efficiency and productivity has been used extensively but its use in the higher education sector has been very limited (only 3.5\% of all the studies published as highlighted by Wolszczak-Derlacz and Parteka (2011)). Unfortunately, the estimates derived through DEA are extremely sensitive to outliers in the data. In addition, with a relatively few higher education producers in most of the countries worldwide, the dimension issue becomes extremely relevant. A simple DEA estimator that does not address the above-mentioned points could produce less reliable and robust productivity estimates.

By following emerging techniques such as the alpha quantile method, the above-mentioned issue can be adequately accommodated in this regard and this is what we did in estimating the efficiency and productivity of the Saudi higher education sector. The studies of Bonaccorsi et al. (2006) and Stocia and Aldea (2016) are the only such studies we could find that have advanced non-parametric methods to estimate efficiencies in Italian and Romanian universities. Hence not only does our study contribute to existing literature on the performance of HEIs in an important country in the region but it also provides reliable estimates of efficiency and productivity that could be used by policymakers in decision-making in relation to efficient resource allocation, employment policies and benchmarking of public sector institutions against privately owned entities.

We conclude that by responding to a huge investment by the government in the physical and human resources of higher education, Saudi HEIs experienced an average productivity improvement of roughly $3 \%$ per annum (p.a.) during the period 2008 to 2014. Older and larger publicly owned institutions experienced a decrease in efficiency but technological progress led to an overall improvement in 
productivity. In relative terms, these institutions are competing well against privately owned institutions in using the available resources efficiently. Very large older public sector institutions have been able to cope with a shift in frontier technology over time and hence have not lagged behind after trying their best to get closer to existing frontier production technology ('catching up'). Higher credit disbursement to the private sector could not help institutions attain technical progress but rather helped them to improve efficiency. Gross capital formation, though, is linked positively to technological progress.

More importantly, bureaucratic red tape does not help educational institutions to catch up with the technology frontier. A better economic situation has allowed HEIs in general and public sector institutions in particular to invest in new learning technologies and help them to achieve technological progress. Interestingly, though, the impact of macroeconomic and labour market conditions appears to be different for public and private sector institutions. Government policy to encourage more female labour participation as enrollees or faculty members in the country's secondary educational system under Vision 2030, however, did not help publicly owned institutions catch up with the frontier technology. The same is true for privately owned institutions in relation to an increase in the percentage of females in the country's tertiary education sector.

The remaining part of the paper is structured as follows. Section 2 contains a description of the institutional set-up of the Saudi higher education sector. A review of literature and our contributions towards the existing knowledge are presented in the subsequent section. Section 4 is comprised of a detailed methodological framework for estimating productivity growth and its sources. The following section (Section 5) presents empirical estimates of the total factor productivity alongside its components, and the last section (Section 6) presents the main conclusions of the study.

\section{Saudi Higher Education Sector}

Saudi Arabia's higher education sector is served by a combination of colleges and universities. Currently, there are 39 universities (29 publicly owned and 10 privately owned) operating across the country alongside 27 other institutions (18 colleges, eight vocational institutions and a military college imparting health-related education). The country has a very high and stable demand for higher education as evidenced by the fact that $44 \%$ of the population in the 25-39 years age category have higher education degrees. The enrolment rates for higher education have been rising and the annual growth rates of graduates produced by different institutions have been in the range of 5-36\%. 
The increase in the demand for higher education has been matched by the employment of more academic and support (administrative) staff. The average annual growth rates in this regard were more than $10 \%$ for academic and more than $15 \%$ for non-academic staff during the period 2011-2015. As well as producing graduates, higher education institutions have been encouraged and obligated by the Ministry of Education (MOE) to perform, publish and disseminate research through reasonable-quality outlets such as journals. As a result of a big push from the MOE, the number of publications has increased. The country's HEIs produced more than 58,000 research pieces during the period 2008-2015. But a major proportion of these (more than $60 \%$ of all publications) were produced by three elite public sector universities, i.e. King Saud University, King Abdulaziz University and King Fahd University of Petroleum and Minerals.

Despite the increasing number of research papers, the quality of these publications is a matter of major concern. Most of the research is concentrated in a few disciplines (science). The lack of quality research in business and management in particular is one area of concern. Historically, government research funding bodies have mostly favoured research projects related to basic and applied sciences. The national quality accreditation bodies are increasingly obligating institutions to prioritize research and allocate a decent share of the institution's budget to quality research. Private institutions that were set up from around 2004 onward are not able to match the giant public sector universities, which have received a phenomenal increase in financial resources from the government to improve research infrastructure and incentivize faculty members to perform and publish research. This has been particularly true during the oil price boom period with increasing opportunities for graduates to secure employment in government due to increased economic activity alongside the Saudization policy.

\section{Efficiency and Productivity Measurement in HE Is - Literature Review}

As mentioned in the introduction section, a number of studies have looked into the measurement of the efficiency and productivity of HEIs. Table 1 presents a summary of some recent empirical studies assessing the efficiency and productivity of HEIs in both developing and developed countries. In summary, the literature review has confirmed that calculating and interpreting technical inefficiency is a common phenomenon in higher education in both developing and developed countries. It also confirms that analysis of the efficiency of the higher education sector typically involves inputs such as labour and capital. Labour is represented by academics, and general and administrative staff. For outputs, the commonly used indicators are the number of graduates and scientific publications alongside a number of other indicators. Interestingly, for Saudi Arabia in particular, and GCC countries in general, we are not able to find a study on the issue that is comprehensive in nature and robust in terms of the chosen methodology. Hence, our study fills this important gap in empirical literature and provides a benchmark 
for the higher education providers in GCC countries in particular (current and potential new entrants) as well as policy planners and government regulatory ministries such as the Saudi MOE. 
Table 1: Summary of empirical literature on higher educational efficiency and productivity

\begin{tabular}{|c|c|c|c|c|}
\hline Authors & Sample & Inputs & Outputs & Main conclusions \\
\hline $\begin{array}{l}\text { Athanasso } \\
\text { poulos } \\
\text { and Shale } \\
\text { (1997) }\end{array}$ & $\begin{array}{l}45 \text { universities from the } \\
\text { UK for the period 1992- } \\
1993\end{array}$ & $\begin{array}{l}\text { number of undergraduates } \\
\text { and postgraduates students } \\
\text { enrolled, academic staff, } \\
\text { mean A-level entry score } \\
\text { over the last } 3 \text { years; } \\
\text { research income, and } \\
\text { expenditure on library and } \\
\text { computing services }\end{array}$ & $\begin{array}{l}\text { number of successful } \\
\text { leavers, number of higher } \\
\text { degrees awarded, and } \\
\text { weighted research rating }\end{array}$ & $\begin{array}{l}\text { universities could be clustered into } 3 \text { main groups: low cost and } \\
\text { high outcome efficiency; high cost and low outcome efficiency; } \\
\text { high cost and high outcome efficiency }\end{array}$ \\
\hline $\begin{array}{l}\text { Joumady } \\
\text { and Ris } \\
(2005)\end{array}$ & $\begin{array}{l}209 \text { HEIs from eight } \\
\text { European countries }\end{array}$ & $\begin{array}{l}\text { teaching characteristics, } \\
\text { equipment, course contents, } \\
\text { intensity of graduate job } \\
\text { search, and quality of the } \\
\text { relation between universities } \\
\text { and the labor market }\end{array}$ & $\begin{array}{l}\text { levels of generic and } \\
\text { vocational competencies } \\
\text { acquired, and } \\
\text { vertical/horizontal } \\
\text { competencies match }\end{array}$ & $\begin{array}{l}\text { UK, the Netherlands and Austria had better performance. France } \\
\text { and Germany were on the other hand located on an average level of } \\
\text { inefficiency; while Spain, Finland and Italy were at the bottom of } \\
\text { the given group }\end{array}$ \\
\hline $\begin{array}{l}\text { Johnes } \\
\text { and Yu } \\
(2008)\end{array}$ & $\begin{array}{l}109 \text { Chinese regular } \\
\text { universities for the period } \\
2003-04\end{array}$ & $\begin{array}{l}\text { staff time, quality of staff, } \\
\text { postgraduate input, research } \\
\text { expenditure and capital } \\
\text { inputs (books and area of } \\
\text { buildings) }\end{array}$ & $\begin{array}{l}\text { index of the prestige of the } \\
\text { HEI, index of total number } \\
\text { of publications, research } \\
\text { publications per academic } \\
\text { staff }\end{array}$ & $\begin{array}{l}\text { geographical location is an important factor as HEIs in the coastal } \\
\text { zone were more efficient but interestingly funding sources were } \\
\text { not. Further, comprehensive universities consistently have higher } \\
\text { average efficiency than a number of specialist institutions in } \\
\text { particular }\end{array}$ \\
\hline $\begin{array}{l}\text { Johnes } \\
(2008)\end{array}$ & $\begin{array}{l}112 \text { HEIs in the UK for } \\
\text { the period } 1997-2005\end{array}$ & $\begin{array}{l}\text { number of full-time } \\
\text { undergraduate and } \\
\text { postgraduate enrolled } \\
\text { students, academic staff, } \\
\text { administrative expenditures, } \\
\text { and expenditures on } \\
\text { centralized academic } \\
\text { services. }\end{array}$ & $\begin{array}{l}\text { degrees awarded (graduate } \\
\text { and postgraduate) and } \\
\text { research income received }\end{array}$ & $\begin{array}{l}\text { HEI's have experienced an annual average increase in productivity } \\
\text { of } 1 \% \text {. Further investigation revealed that HEI's have in fact } \\
\text { enjoyed an annual average increase in technological progress of } 6 \% \\
\text { combined with a decrease in technical efficiency of 5\%. Rapid } \\
\text { changes in the higher education sector appear to have had a positive } \\
\text { effect on the technology of production but this has been achieved at } \\
\text { the cost of lower technical efficiency. }\end{array}$ \\
\hline $\begin{array}{l}\text { Aubyn } \text { et } \\
\text { al. (2009) }\end{array}$ & $\begin{array}{l}\text { EU, Japan and USA } \\
\text { public or government } \\
\text { dependent HEIs using the } \\
\text { period 1998-2005 }\end{array}$ & $\begin{array}{l}\text { academic staff and number } \\
\text { of students }\end{array}$ & $\begin{array}{l}\text { number of graduates, THES } \\
\text { - QS recruiter survey } \\
\text { ranking, THES - QS peer } \\
\text { survey ranking and } \\
\text { published articles and } \\
\text { citations }\end{array}$ & $\begin{array}{l}\text { institutions from countries such as Ireland, Japan, Sweden, UK and } \\
\text { the Netherlands were very close to the efficient frontier while } \\
\text { countries such as Bulgaria, Spain, Hungary, Czech Republic, } \\
\text { Slovakia, Estonia, Portugal and Greece were found to be highly } \\
\text { inefficient }\end{array}$ \\
\hline $\begin{array}{l}\text { Agasisti } \\
\text { and Perez- } \\
\text { Esparrells } \\
(2010)\end{array}$ & $\begin{array}{l}57 \text { and } 46 \text { Italian and } \\
\text { Spanish public universities } \\
\text { covering the period } 2003 \\
\text { and } 2004\end{array}$ & $\begin{array}{l}\text { number of enrolled students, } \\
\text { number of enrolled PhD } \\
\text { students, number of } \\
\text { academic staff, and financial } \\
\text { resources }\end{array}$ & $\begin{array}{l}\text { number of graduates and } \\
\text { amount of external income } \\
\text { attracted to research } \\
\text { activities were used }\end{array}$ & $\begin{array}{l}\text { Italy, improvement of performance over time was due to major } \\
\text { technological changes, while in Spain it was due to "pure" } \\
\text { efficiency (arising from new funding models) }\end{array}$ \\
\hline $\begin{array}{l}\text { Eckles } \\
(2010)\end{array}$ & $\begin{array}{l}93 \text { private liberal arts } \\
\text { colleges in } 27 \text { states in } \\
\text { USA for the period } 2006-\end{array}$ & $\begin{array}{l}\text { cost per undergraduate, } \\
\text { number of full time faculty, } \\
\text { students in the top } 10 \% \text { of }\end{array}$ & Six-year graduation rates & $\begin{array}{l}18 \text { colleges are found to be technically efficient. The study } \\
\text { subsequently identified peers for each of the technically inefficient } \\
\text { institutions for any improvement in operations }\end{array}$ \\
\hline
\end{tabular}




\begin{tabular}{|c|c|c|c|c|}
\hline & 2007 & $\begin{array}{l}\text { their high school class, and } \\
25^{\text {th }} \text { percentile of entering } \\
\text { students' SAT scores }\end{array}$ & & \\
\hline $\begin{array}{l}\text { Kantabutr } \\
\text { a and } \\
\text { Tang } \\
(2010)\end{array}$ & $\begin{array}{l}22 \text { Thai universities for } \\
\text { the period 2003-2006 }\end{array}$ & $\begin{array}{l}\text { annual operating budget, } \\
\text { number of academic staff, } \\
\text { number of non-academic } \\
\text { staff, amount of internal and } \\
\text { external research fund }\end{array}$ & $\begin{array}{l}\text { number of graduates at the } \\
\text { undergraduate/master degree } \\
\text { levels, employment rate, } \\
\text { number of publications in } \\
\text { internationally/nationally } \\
\text { refereed journals, number of } \\
\text { PhD degrees }\end{array}$ & $\begin{array}{l}\text { public universities in Thailand were more efficient in teaching than } \\
\text { in research activity }\end{array}$ \\
\hline $\begin{array}{l}\text { Wolszcza } \\
\text { k-Derlacz } \\
\text { and } \\
\text { Partera } \\
(2011)\end{array}$ & $\begin{array}{l}259 \text { public universities } \\
\text { from Austria, Finland, } \\
\text { Germany, Italy, Poland, } \\
\text { UK and Switzerland for } \\
\text { the period 2001-05 }\end{array}$ & $\begin{array}{l}\text { total academic staff, total } \\
\text { number of students and total } \\
\text { revenues }\end{array}$ & $\begin{array}{l}\text { number of graduations and } \\
\text { number of scientific } \\
\text { publications }\end{array}$ & $\begin{array}{l}5 \% \text { of sample HEIs are } 100 \% \text { efficient. Interestingly, universities } \\
\text { from Switzerland obtained the best efficiency scores }\end{array}$ \\
\hline $\begin{array}{l}\text { Cunha } \\
\text { and Rocha } \\
(2012) \text {, }\end{array}$ & $\begin{array}{l}14 \text { public universities, } 20 \\
\text { public polytechnics, and } \\
14 \text { faculties of University } \\
\text { of Porto in Portugal in } \\
2008\end{array}$ & $\begin{array}{l}\text { total funding per student, } \\
\text { total expenditure per student, } \\
\text { and academic staff per } \\
\text { student }\end{array}$ & $\begin{array}{l}\text { total graduate students, total } \\
\text { PhD degrees awarded and } \\
\text { total number of courses }\end{array}$ & $\begin{array}{l}\text { only } 14.3 \% \text { of public universities were most technically efficient, } \\
\text { and } 20 \% \text { of public polytechnics }\end{array}$ \\
\hline $\begin{array}{l}\text { Stoica and } \\
\text { Aldea } \\
(2016)\end{array}$ & $\begin{array}{l}89 \text { Romanian universities } \\
\text { for the period } 2008-2009\end{array}$ & $\begin{array}{l}\text { academic staff weighted } \\
\text { according to their academic } \\
\text { position, academic personal } \\
\text { and number of books in the } \\
\text { university library. human } \\
\text { resources, indicator for the } \\
\text { university size and the } \\
\text { financial resources }\end{array}$ & $\begin{array}{l}\text { high quality ISI publications } \\
\text { and IDB papers. number of } \\
\text { graduate students }\end{array}$ & $\begin{array}{l}\text { trade-offs between teaching and research activities shows as an } \\
\text { increased effort in the Romanian universities to increase their } \\
\text { ranking by investing in the research area even with the reduce } \\
\text { funding }\end{array}$ \\
\hline $\begin{array}{l}\text { Alshayea } \\
\text { et al. } \\
\text { (2013) }\end{array}$ & $\begin{array}{l}19 \text { faculties of Anbar } \\
\text { University in Iraq for the } \\
\text { years } 2011 \text { and } 2012\end{array}$ & academic and general staff & $\begin{array}{l}\text { number of graduates and } \\
\text { number of research } \\
\text { publications }\end{array}$ & $\begin{array}{l}\text { different departments of the university achieved on average a } \\
\text { productivity growth of } 7.6 \% \text { mainly due to efficiency improvement } \\
\text { while university experienced a significant technological regress }\end{array}$ \\
\hline
\end{tabular}




\section{Estimation of Efficiency and Productivity}

A significant effort has been made on the methodological front to develop a robust and widely accepted efficiency estimator but a consensus has still not been reached among theorists and practitioners (see Wheelock \& Wilson $(2003,2008)$ on some important issues of various non-parametric estimators). Two widely used estimators, i.e. stochastic frontier analysis and DEA, are subject to a number of issues (see Authors (2015) for details, among others). DEA in particular is going through a significant methodological development to address outlier and statistical inference issues. The estimator developed by Wheelock and Wilson $(2008,2009)$ based on an unconditional $\alpha$-quantile hyperbolic frontier is considered robust, treats outlier observations better, and is suitable when using a low number of observations and thus avoids the curse of dimensions. This study uses this estimator to estimate the efficiency of Saudi higher education institutions. As a comparison, we also use efficiency estimation using simple DEA, Free Disposal Hull (FDH) and partial frontier (order-m) to stress the importance of using a suitable estimator in estimating and explaining the efficiency score for each decision-making unit (DMU). We do not report estimates here but these results are available from the corresponding author upon request.

\section{Methodology}

By following the notations, conventions, definitions and procedures of Wheelock and Wilson (2008, 2009), we briefly discuss the hyperbolic order- $\alpha$ quantile estimator. For a very simple case, assume an educational institution uses human capital, which in efficiency literature is known as input quantities (p) that include academic and administrative staff to produce two output quantities (q) such as the number of graduates and publications. By following the literature on efficiency estimations, one could define a standard production possibility set as $\boldsymbol{p}^{t} \equiv\{(x, y) \mid x$ which can produce $y$ at time $\mathrm{t}\} \subset \mathbb{R}_{+}^{p+q}$. The input and output vectors can be represented by p input quantities as $x \in \mathbb{R}_{+}^{p}$ and q output quantities as $y \in \mathbb{R}_{+}^{q}$ representing a feasible combination of input and output in a particular time period. In a broader context, $\boldsymbol{p}^{t \partial}$ in this case represents an upper boundary or benchmark of production frontier $\boldsymbol{p}^{t}$. It is customary to estimate distance from an arbitrary point $(x, y) \in \mathbb{R}_{+}^{p+q}$ to the boundary $\boldsymbol{p}^{t \partial}$ along an assumed direction such as input minimization or output maximization.

Despite significant progress in establishing statistical properties of DEA and FDH estimators, it has been established that both suffer from some serious issues such as slow convergence rates, arbitrary choice of input/output orientation and outlier effect and thus require many observations to obtain reliable efficiency estimates. The DEA-based hyperbolic distance function avoids the orientation issue but outlier and 
dimension issues still remain unresolved. Recently, some authors using the partial frontier concept developed a new generation of estimators including the "order- $\alpha$ quantile estimator" . Wheelock and Wilson (2008) further refined and developed a statistical model of the $\alpha$ quantile estimator. In developing the model, the authors introduced some statistical assumptions such as production set $\boldsymbol{p}^{t}$ is compact and free disposal, sample observations $\mathcal{S}_{n t}^{t}=\left\{\left(x_{\mathrm{i}}, y_{\mathrm{i}}\right)\right\}_{\mathrm{i}=1}^{\mathrm{n}}$ being realization of identically independently distributed (iid) random variables with probability density function $f(x, y)$ with support vector $\mathrm{P}^{t}$. In this context, any point $(x, y)$ is said to be on the frontier of $\mathrm{p}^{\mathrm{t}}$, let's say $\boldsymbol{p}^{t \partial}$, if $\left\{\left(\gamma^{-1} x, \gamma y\right)\right\} \notin \boldsymbol{p}^{t}$ for any $\gamma>1$. Furthermore, at the frontier, the density $f_{\mathrm{t}}$ is strictly positive and sequentially Lipschitz continuous.

Under this framework, the authors defined the above density function $f^{t}(x, y)$ as a probability function as follows:

$$
H^{t}\left(x_{0}, y_{0}\right)=\operatorname{pr}\left(x \leq x_{0}, y \geq y_{0} \text { at time } t\right)
$$

The above function (1) gives the probability of drawing an observation from $f(x, y)$ that weakly dominates the DMU operating at $\left(x_{0}, y_{0}\right)$. The dominance idea is based on the fact that firms are compared in terms of their identity and similarity in the use of input mix in the production of output. In this context, the hyperbolic approach is based on the idea of dominance. By rigidly following Wheelock and Wilson (2008) and using $H(.,$.$) , the hyperbolic distance function is written as:$

$$
\gamma^{t}\left(x, y \mid \boldsymbol{p}^{t}\right)=\sup \left\{\gamma>0 \mid H\left(\gamma^{-1} x, \gamma y\right)>0\right\}(2)
$$

while the hyperbolic $\alpha$-quantile distance function is defined as:

$$
\gamma_{\alpha}^{t}(x, y)=\sup \left\{\gamma>0 \mid H^{t}\left(\gamma^{-1} x, \gamma y\right)>(1-\alpha)\right\}
$$

and the hyperbolic $\alpha$-quantile frontier is further defined as:

$$
\boldsymbol{p}_{\alpha}^{t \partial}=\left\{\gamma_{\alpha}^{t}(x, y)^{-1} x, \gamma_{\alpha}^{t}(x, y) y \mid(x, y) \in \boldsymbol{p}^{t}\right\}
$$

\footnotetext{
${ }^{1}$ See Cazal et al. (2002) for the 'order-m' estimator and Daouia (2003), Aragan et al. (2005) and Daouia and Simar (2007) for the conditional/unconditional 'order- $\alpha$ ' quantile.
} 
The empirical analogue of the above equation (9) for the estimation of $\boldsymbol{\gamma}_{\boldsymbol{\alpha}}^{\boldsymbol{t}}(\boldsymbol{x}, \boldsymbol{y})$ and corresponding $\boldsymbol{p}_{\boldsymbol{\alpha}}^{\boldsymbol{t} \boldsymbol{\partial}}$ for the observations in $\boldsymbol{S}_{\boldsymbol{n} t}^{\boldsymbol{t}}$ is subsequently defined as:

$$
\widehat{\mathrm{H}}_{n}\left(x_{0}, y_{0} \mid \mathcal{S}_{\mathrm{nt}}^{\mathrm{t}}\right)=n_{t}^{-1} \sum_{i=1}^{n} \mathrm{I}\left(x_{i} \leq x_{0}, y_{i} \geq y_{0} \mid\left(x_{i}, y_{i}\right) \in \mathcal{S}_{\mathrm{nt}}^{\mathrm{t}}\right)
$$

Now with I( $\cdot)$ as an indicator function, the estimator of $\boldsymbol{\gamma}_{\boldsymbol{\alpha}}^{\boldsymbol{t}}(\boldsymbol{x}, \boldsymbol{y})$ is developed by replacing $\mathrm{H}(\cdot, \cdot)$ with $\widehat{\mathbf{H}}\left(\cdot, \cdot \mid \boldsymbol{S}_{\mathrm{nt}}^{\mathbf{t}}\right)$ to get the following:

$$
\hat{\gamma}_{\alpha, n t}^{t}(x, y)=\sup \left\{\gamma>0 \mid \widehat{\mathrm{H}}_{n}\left(\gamma^{-1} x, \gamma y \mid \mathcal{S}_{\mathrm{nt}}^{\mathrm{t}}\right)>(1-\alpha)\right\}
$$

Based on the above, computation of $\hat{\gamma}_{\alpha, n t}^{\mathrm{t}}(\mathrm{x}, \mathrm{y})$ turns into a univariate issue and an exact solution is achieved to derive the estimator of the conditional $\alpha$-quantile distance function. Based on a point $\left(\mathrm{x}_{0}, \mathrm{y}_{0}\right)$, the initial values $\gamma_{a}, \gamma_{b}$ are found that bracket the solution in the sense that $\left(\widehat{\mathrm{H}}_{\mathrm{n}}\left(\gamma_{\mathrm{a}}^{-1} x_{0}, \gamma_{\mathrm{a}} \mathrm{y}_{0} \mid \mathcal{S}_{\mathrm{nt}}^{\mathrm{t}}\right)<\right.$ $(1-\alpha)$ and $\left(\widehat{\mathrm{H}}_{\mathrm{n}}\left(\gamma_{\mathrm{b}}^{-1} x_{0}, \gamma_{\mathrm{b}} \mathrm{y}_{0} \mid \mathcal{S}_{\mathrm{nt}}^{\mathrm{t}}\right)<(1-\alpha)\right.$. Some additional steps involve solving for $\hat{\gamma}_{\alpha, n}\left(x_{0}, y_{0}\right)$ by utilizing the bisection method. At the estimation stage, however, the choosing of $\alpha$ is a very important factor to be considered by the researcher. We tried different values for $\alpha$ but report efficiency estimates for $\alpha=0.85$ to conserve space.

\section{Malmquist productivity index and its components}

Following Wheelock and Wilson (2009), an index of efficiency change over two time periods is calculated by the ratio $\gamma_{\alpha}^{t_{2}}\left(x_{i t 2}, y_{i t 2}\right) / \gamma_{\alpha}^{t_{1}}\left(x_{i t 1}, y_{i t 1}\right)$. In this case, a value less than unity would imply an increase in technical efficiency in the current period $\left(\mathrm{t}_{1}\right)$ compared to the reference period $\left(\mathrm{t}_{2}\right)$ relative to $\alpha$-quantiles at time $t_{1}$ and $t_{2}$. An industry-level performance measure of efficiency change is computed by the geometric mean of this ratio. For a quantile-based measure of efficiency, the change in efficiency between two time periods $t_{1}$ and $t_{2}$ is calculated as:

$$
\mathcal{E}_{\alpha}\left(t_{1}, t_{2}\right)=\left[\prod_{i \in \mathbf{T}} \frac{\gamma_{\alpha}^{t_{2}}\left(x_{i t 2}, y_{i t 2}\right)}{\gamma_{\alpha} t_{1}\left(x_{i t 1}, y_{i t 1}\right)}\right]^{\frac{1}{\# \mathbf{T}\left(t_{1}, t_{2}\right)}}
$$

where $\varepsilon_{\alpha}\left(t_{1}, t_{2}\right)$ is the mean change in efficiency between time periods $t_{1}$ and $t_{2}$, relative to the unconditional, hyperbolic $\alpha$-quantile at time $t_{1}$ and $t_{2}$, whereas $\left(t_{1}, t_{2}\right)$ is the set of institutions in existence in both time periods and $\#_{\mathbf{T}}\left(t_{1}, t_{2}\right)$ is the number of institutions in the set. A dynamic measure of the productivity index proposed by Färe et al. (1985) between the two time periods $t_{1}$ and $t_{2}$ called 
Malmquist's productivity index is estimated by first estimating the unconditional hyperbolic $\alpha$-quantile. The Malmquist productivity index can be defined $a^{2}$ :

$\mathbf{M}_{\alpha}\left(t_{1}, t_{2}\right)=\left\{\left[\prod_{i \in \mathbf{T}}\left(t_{1}, t_{2}\right) \frac{\gamma\left(\left(x_{i t 2}, y_{i t 2} \mid \mathrm{V}\left(\boldsymbol{p}_{\alpha}^{t_{1}}\right)\right)\right.}{\gamma\left(\left(x_{i t 1}, y_{i t 1} \mid \mathrm{V}\left(\boldsymbol{p}_{\alpha}^{t_{1}}\right)\right)\right.} \times \frac{\gamma\left(\left(x_{i t 2}, y_{i t 2} \mid \mathrm{V}\left(\boldsymbol{p}_{\alpha}^{t_{2}}\right)\right)\right.}{\gamma\left(\left(x_{i t 1}, y_{i t 1} \mid \mathrm{V}\left(\boldsymbol{p}_{\alpha}^{t_{2}}\right)\right)\right.}\right]^{1 / 2}\right\}^{\frac{1}{\# \mathbf{T}\left(t_{1}, t_{2}\right)}}$

This index calculates the mean (geometric) change in the productivity of the educational institution from time $t_{1}$ to $t_{2}$ due to either a change in efficiency (first component in equation (8)) or technological progress/regress (second component in equation (8)). As discussed by Wheelock and Wilson (2009), this measure is considered to be the same in terms of its composition, but it is also different in two ways to Färe et al.'s (1985) measure. First and most importantly, productivity is benchmarked against $\alpha$-quantile boundaries, and second, to avoid the complications highlighted in the above discussion, a hyperbolic direction is utilized rather than the input or output orientation. Here, in the above equation (8), M $<1$ would indicate an increase in productivity and $\mathrm{M}>1$ corresponds to a productivity decline.

\section{Modelling the determinants of productivity and its component estimates}

The efficiency and productivity estimates derived from the above-mentioned estimator are first explained in terms of trends over time alongside some descriptive statistics of these estimates. In an effort to further understand the productivity differential across different institutions and over time, productivity growth and its components are then regressed on a number of explanatory variables comprising institutionspecific ones, and prevailing labour market and economic conditions. The institution-specific variables include dummy variables for type of institution (=' 1 ' if the institution is a university and ' 0 ' otherwise such as a college), ownership type $(=' 1$ ' if the institution is publicly owned and ' 0 ' otherwise such as privately owned), type of education provided $\left(={ }^{\circ} 1^{\prime}\right.$ if the institution is a general education provider (comprehensive) and ' 0 ' otherwise such as technical education), and medical education provider (=' 1 ' if the institution is a medical education provider and ' 0 ' otherwise such as technical education). The age of the institution entered as a dummy variable in the regression model $\left(={ }^{\prime} 1\right.$ ' if the institution was established $>=20$ years ago and categorized as old and ' 0 ' otherwise). Lastly two continuous institution-specific variables are the ratio of numbers of graduates produced/academic staff and the number of Scopus-listed publications/administrative staff.

\footnotetext{
${ }^{2}$ For details see Wheelock and Wilson (2009, p. 361).
} 
After controlling for institution-specific factors, a set of variables containing labour market and macroeconomic conditions are selected including the employment to population ratio, the lower secondary completion rate, the percentage of students in secondary education who are female and tertiary education academic staff who are female. Macroeconomic factors that could have an impact include domestic credit to the private sector, GDP per capita growth, gross capital formation and ease of doing business measured by the time required to start a business. These variables are selected based on evidence from the existing empirical literature and relevance to the Saudi labour market. In theory, favourable macroeconomic and labour market conditions are expected to contribute positively towards improvement in productivity and its components.

Given the fact that institution-specific variables do not vary over time and some private institutions are very small, producing very few publications and graduates compared to giant public sector HEIs dealing with thousands of students and producing thousands of publications per year, we chose a panel data random effect model for our estimation strategy. In the context of educational research, while discussing which method to use (fixed vs random effect model), Clarke et al. (2010) state that [when] a researcher has access to rich data, the random effects model should be preferred because it can produce policyrelevant estimates while allowing a wider range of research questions to be addressed. We have a relatively rich data set covering almost $95 \%$ of Saudi higher education providers. We also carried out a number of tests to ensure that our choice of estimator is appropriate for the regression analysis. Broadly speaking, the Hausman test confirmed that random effect choice is justified over fixed effect. In addition, given the fact that we aimed to include a number of time-invariant explanatory variables (such as type of institution, ownership, old/new etc.) in our regression framework, this would require us to use an estimator other than fixed effect. The Breusch-Pagan Lagrange multiplier (LM) test, which helps in deciding between a random effects regression and a simple OLS regression, confirmed our selection for our main interest dependent variable (technological change given the fact that productivity change appears to as a result of positive technical change in most cases as discussed before) in particular. Furthermore, our pooled regression OLS estimates are not entirely different in terms of the magnitude or signs of the coefficients attached to all explanatory variables.

\section{Choice of inputs and outputs and sources of data}

Following several studies mentioned in the literature review of this paper and because of the absence of data on the financial resources of universities and other variables, we employed a production approach and used two inputs and two outputs. In simple terms, we assume that Saudi HEIs combine factors of production (academic and non-academic labour) to produce output in the form of graduates and the number of research papers published in recognized journals (Scopus listed). As mentioned above, 
contrary to many studies in this area cited in the introduction and literature review section, we confined ourselves to these inputs and outputs due to data availability issues at the institutional level. The two inputs are academic and administrative staff. The outputs are the number of graduates and publications. The data for academic staff, administrative staff and graduates were gathered from the MOE website, while the data for publications were gathered from the Scopus database. Table 2 contains descriptive statistics of the inputs and outputs used in the study (aggregated and classified by ownership of the institutions).

Table 2: Descriptive statistics of outputs and inputs used

\begin{tabular}{|c|c|c|c|c|c|}
\hline Variable & \# of Obs. & Mean & Std. Dev. & Min & $\operatorname{Max}$ \\
\hline \multicolumn{6}{|c|}{ Overall } \\
\hline Academic staff & 319 & 1037.505 & 1563.735 & 12 & 7889 \\
\hline General staff & 319 & 941.592 & 2335.141 & 6 & 26775 \\
\hline Number of graduates & 319 & 2565.771 & 4279.691 & 1 & 24675 \\
\hline Number of Scopus listed publication & 319 & 177.759 & 599.677 & 1 & 5119 \\
\hline \multicolumn{6}{|c|}{ Publicly owned HEIs } \\
\hline Academic staff & 172 & 1836.913 & 1773.042 & 56 & 7889 \\
\hline General staff & 172 & 1665.343 & 2998.585 & 44 & 26775 \\
\hline Number of graduates & 172 & 4605.849 & 4988.656 & 1 & 24675 \\
\hline Number of Scopus listed publication & 172 & 316.023 & 790.908 & 1 & 5119 \\
\hline \multicolumn{6}{|c|}{ Privately owned HEIS } \\
\hline Academic staff & 147 & 102.143 & 101.325 & 12 & 677 \\
\hline General staff & 147 & 94.755 & 80.800 & 6 & 384 \\
\hline Number of graduates & 147 & 178.742 & 324 & 1 & 2159 \\
\hline Number of Scopus listed publication & 147 & 15.980 & 41.765 & 1 & 268 \\
\hline \multirow{2}{*}{\multicolumn{6}{|c|}{$\begin{array}{l}\text { It is clear from these numbers that there appear to be a lot of variations in both inputs and outputs, and the } \\
\text { potential of outliers in the data is a real possibility and thus provides justification for the methodology }\end{array}$}} \\
\hline & & & & & \\
\hline \multicolumn{6}{|c|}{ used to estimate the relevant distance function. We used subsequently these to estimate productivity index } \\
\hline \multirow{2}{*}{\multicolumn{6}{|c|}{$\begin{array}{l}\text { and its components. In addition, it also confirms a significant heterogeneity across two ownership types } \\
\text { (public vs private) in both input usage and output produced. The private institutions appear to be }\end{array}$}} \\
\hline & & & & & \\
\hline \multicolumn{6}{|c|}{ significantly smaller than publicly owned HEIs, but interestingly, the faculty/administrator ratio happens } \\
\hline \multirow{2}{*}{\multicolumn{6}{|c|}{$\begin{array}{l}\text { to be almost the same. The ratio of graduates produced and publications to academic staff and } \\
\text { administrative staff shows that publicly owned institutions appear to be producing more graduates per }\end{array}$}} \\
\hline & & & & & \\
\hline \multicolumn{6}{|c|}{ faculty. The publications/academic or admin staff ratio does not show any significant difference between } \\
\hline \multicolumn{6}{|c|}{ the two ownerships ( 0.17 and 0.19 for publicly owned compared to 0.16 and 0.17 for privately owned } \\
\hline \multicolumn{6}{|c|}{ institutions). Next we track the two ratios for the overall sector and the outcome of this is contained in } \\
\hline \multirow{2}{*}{\multicolumn{6}{|c|}{$\begin{array}{l}\text { Figures } 1 \text { and } 2 \text {. It appears that the graduates to admin or academic staff ratio has increased a bit over } \\
\text { time but the publications ratio has significantly improved, although it is still significantly below the MOE }\end{array}$}} \\
\hline & & & & & \\
\hline & & & & & \\
\hline
\end{tabular}




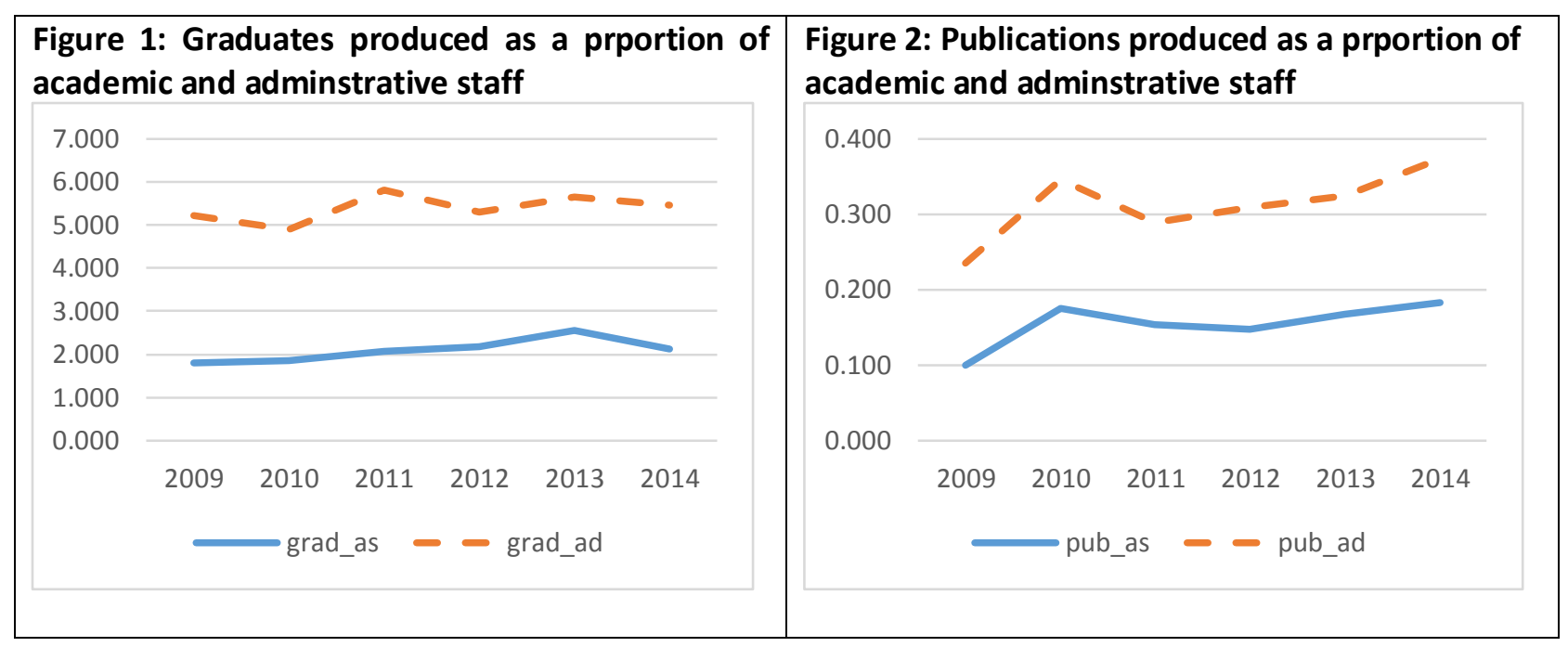

Table 3 shows the trend in these macroeconomic and labour market condition variables, which are subsequently used in our regression framework to explain the trend in productivity and its components. Starting with three important labour market condition variables (employment to population ratio, lower secondary completion rate and female faculty percentage in tertiary education), the trend on average seems to be upward over time compared to the slightly downward trend in the percentage of female students in secondary general education. The decline could perhaps be due to male students continuing their education for longer compared to the total population of students rather than the decrease in female participation rates (as females have been encouraged by the state through scholarships and other benefits). The next set of variables are related to the prevailing macroeconomic conditions in the Kingdom. GDP per capita fluctuated a lot during the sample period and generally speaking fell over this period in comparison to 2010/2011. The same can be said of gross capital formation. No specific trend is noticed for domestic credit to the private sector. Business conditions measured by the time it takes to start a business improved a bit during the sample period.

Table 3: Trend in macroeconomic and labour market conditions

\begin{tabular}{|c|c|c|c|c|c|c|}
\hline & 2009 & 2010 & 2011 & 2012 & 2013 & 2014 \\
\hline Employment to population ratio, $15+$, total (\%) (national estimate) & 47.20 & 48.20 & 50.10 & 50.80 & 51.10 & 50.90 \\
\hline Lower secondary completion rate, total ( $\%$ of relevant age group) & 90.15 & 99.17 & 97.40 & 95.29 & 96.30 & 97.77 \\
\hline Percentage of students in secondary general education who are female $(\%)$ & 48.23 & 47.91 & 47.89 & 48.29 & 46.03 & 44.35 \\
\hline Tertiary education, academic staff ( $\%$ female) & 34.69 & 36.52 & 38.02 & 36.96 & 38.94 & 40.49 \\
\hline Domestic credit to private sector ( $\%$ of GDP) & 45.63 & 39.27 & 34.19 & 36.44 & 40.34 & 44.44 \\
\hline GDP per capita growth (annual \%) & -0.65 & 2.22 & 7.29 & 2.86 & 0.27 & 1.34 \\
\hline Gross capital formation (\% of GDP) & 31.72 & 30.74 & 26.78 & 26.34 & 26.24 & 28.51 \\
\hline Time required to start a business (days) & 24.20 & 24.20 & 24.20 & 21.20 & 21.70 & 21.70 \\
\hline
\end{tabular}

Source: World Development Indicators (various issues) 


\section{Empirical Productivity Estimates}

The productivity estimates contained in Table 4 below show that on average, Saudi HEIs experienced an improvement in productivity of roughly $3 \%$ per annum (p.a.) mainly due to technological progress despite experiencing a $2 \%$ efficiency decline over the six-year period. Looking specifically at individual years, 2009 was the only year when HEIs experienced a technological regress alongside a decline in efficiency, resulting in a productivity decline of more than 6\%. In contrast, 2011 and 2014 were the only years that saw an improvement in efficiency. There could have been a number of reasons for the improved productivity resulting from technological progress in these years in particular. We discuss these reasons for, and determinants of, this improvement in our next subsection.

In an effort to better understand the role of ownership in determining productivity and its sources, we divide the institutions into two parts: one owned by private businesses and the second state/publicly owned. Table 4 contains productivity estimates and components for institutions of both ownership types. These estimates show that on average, and similarly to industry overall, both private and public sector institutions experienced an improvement in productivity of almost 3\% p.a. It is interesting to observe that irrespective of ownership, institutions witnessed an improvement in productivity due to technological progress alone. Publicly owned institutions in fact experienced a decrease in efficiency in almost all sample years due perhaps to diseconomies of scale, but at the same time technological progress led to the offsetting of the efficiency decline. Technological progress could be due to the increasing use and application of new learning technologies such as e-learning by both public and private HEIs. Private institutions did experience an improvement in efficiency in four out of the six sample years, but a huge decline in 2010 and 2012 made the overall change neutral. These institutions, on the other hand, did not witness technological progress for three out of the six years in contrast to a decline in efficiency for only two years. Interestingly, contrary to the general perception that public sector institutions suffer from inertia and lag behind in terms of using newer technology, these institutions have been able to compete against newer and modern private universities in adopting and implementing new learning processes.

Table 4 contains productivity estimates and components for different types of institutions as per the degree to which these institutions offers i.e. general educations, health/medical and vocational. Starting with general education provider institutions, it is clear that on average, these institutions experienced only a $1 \%$ improvement in productivity compared to an overall $3 \%$ for all educational institutions. Interestingly, these institutions experienced a 5.5\% decline in efficiency (the highest among all types), but thankfully the technological progress of $6.3 \%$ led to an overall small improvement in productivity for these types of institutions. Interestingly, the decline in efficiency was almost matched by an improvement in technology for almost all sample years for these institutions. Health education provider institutions 
experienced a productivity improvement of $4.6 \%$ p.a., attributed to both technological progress and improvement in efficiency. These institutions did not experience an improvement in efficiency or technological progress for two out of the six years of our sample period. In terms of trends, very similar conclusions can be drawn for vocational education provider institutions, which witnessed a significant improvement in productivity (roughly $12 \%$ p.a.) due mainly to improved efficiency of almost the same magnitude. This highest increase among the Kingdom's educational institutions could be due to fewer observations in our sample in relation to these institutions. These institutions did not experience any technological progress worth mentioning (just a meagre $0.6 \%$ ) compared to all other institutions.

Table 4: Saudi HEIs productivity estimates

\begin{tabular}{|c|c|c|c|c|c|c|c|}
\hline & 2009 & 2010 & 2011 & 2012 & 2013 & 2014 & overall \\
\hline \multicolumn{8}{|c|}{ Overall } \\
\hline efficiency change & 1.028 & 1.057 & 0.975 & 1.129 & 1.004 & 0.969 & 1.023 \\
\hline technical change & 1.039 & 0.851 & 0.980 & 0.875 & 0.975 & 0.98 & 0.950 \\
\hline productivity change & 1.069 & 0.899 & 0.955 & 0.988 & 0.979 & 0.949 & 0.971 \\
\hline & \multicolumn{7}{|c|}{ publically owned institutions } \\
\hline efficiency change & 1.164 & 1.000 & 1.011 & 1.035 & 1.030 & 1.004 & 1.037 \\
\hline technical change & 0.962 & 0.901 & 0.923 & 0.927 & 0.996 & 0.909 & 0.937 \\
\hline \multirow[t]{2}{*}{ productivity change } & 1.120 & 0.902 & 0.933 & 0.959 & 1.026 & 0.912 & 0.971 \\
\hline & \multicolumn{7}{|c|}{ privately owned institutions } \\
\hline efficiency change & 0.876 & 1.133 & 0.939 & 1.241 & 0.974 & 0.929 & 1.007 \\
\hline technical change & 1.150 & 0.791 & 1.044 & 0.823 & 0.951 & 1.071 & 0.965 \\
\hline \multirow[t]{2}{*}{ productivity change } & 1.007 & 0.896 & 0.980 & 1.021 & 0.926 & 0.995 & 0.972 \\
\hline & \multicolumn{7}{|c|}{ general education provider institutions } \\
\hline efficiency change & 1.107 & 1.110 & 1.006 & 1.102 & 1.033 & 1.003 & 1.055 \\
\hline technical change & 0.999 & 0.851 & 0.981 & 0.867 & 0.976 & 0.954 & 0.937 \\
\hline \multirow[t]{2}{*}{ productivity change } & 1.106 & 0.945 & 0.986 & 0.955 & 1.008 & 0.957 & 0.989 \\
\hline & \multicolumn{7}{|c|}{ health/medical/medicine education provider institutions } \\
\hline efficiency change & 0.884 & 1.113 & 0.850 & 1.298 & 0.908 & 0.916 & 0.979 \\
\hline technical change & 1.142 & 0.800 & 0.993 & 0.872 & 0.958 & 1.095 & 0.974 \\
\hline \multirow[t]{2}{*}{ productivity change } & 1.010 & 0.891 & 0.844 & 1.132 & 0.870 & 1.003 & 0.954 \\
\hline & \multicolumn{7}{|c|}{ vocational education provider institutions } \\
\hline efficiency change & 0.841 & 0.635 & 1.070 & 0.937 & 1.013 & 0.879 & 0.887 \\
\hline technical change & 1.131 & 0.974 & 0.921 & 1.014 & 0.998 & 0.934 & 0.994 \\
\hline productivity change & 0.952 & 0.619 & 0.985 & 0.950 & 1.011 & 0.821 & 0.881 \\
\hline & & & & college & & & \\
\hline efficiency change & 0.879 & 1.056 & 0.909 & 1.147 & 0.947 & 0.911 & 0.966 \\
\hline technical change & 1.146 & 0.825 & 1.039 & 0.880 & 0.961 & 1.055 & 0.983 \\
\hline \multirow[t]{2}{*}{ productivity change } & 1.007 & 0.871 & 0.944 & 1.009 & 0.910 & 0.961 & 0.949 \\
\hline & \multicolumn{7}{|c|}{ universities } \\
\hline efficiency change & 1.119 & 1.058 & 1.013 & 1.120 & 1.045 & 1.011 & 1.058 \\
\hline technical change & 0.987 & 0.864 & 0.949 & 0.873 & 0.985 & 0.931 & 0.930 \\
\hline \multirow[t]{2}{*}{ productivity change } & 1.104 & 0.913 & 0.962 & 0.977 & 1.029 & 0.941 & 0.985 \\
\hline & \multicolumn{7}{|c|}{ newer institutions (age $<20$ years) } \\
\hline efficiency change & 1.029 & 1.172 & 0.949 & 1.177 & 0.996 & 0.973 & 1.039 \\
\hline technical change & 1.080 & 0.833 & 1.030 & 0.868 & 0.998 & 0.997 & 0.966 \\
\hline \multirow[t]{2}{*}{ productivity change } & 1.112 & 0.976 & 0.977 & 1.022 & 0.993 & 0.971 & 1.004 \\
\hline & \multicolumn{7}{|c|}{ older institutions (age > 20 years) } \\
\hline efficiency change & 1.027 & 0.795 & 1.075 & 0.977 & 1.034 & 0.952 & 0.973 \\
\hline technical change & 0.942 & 0.901 & 0.821 & 0.900 & 0.900 & 0.919 & 0.897 \\
\hline productivity change & 0.968 & 0.717 & 0.882 & 0.880 & 0.930 & 0.875 & 0.874 \\
\hline
\end{tabular}


Table 4 contains productivity estimates for two types of institutions, i.e. colleges and universities. The comparison of these institutions clearly shows that productivity was improving in both colleges and universities. The improvement in productivity for colleges was roughly $5 \%$ p.a. while it was $1.5 \%$ p.a. for universities. In terms of components of productivity, colleges experienced improved efficiency for two out of the six years and technological progress for three out of the six years. In contrast, the improvement in productivity for universities was entirely contributed by technological progress for all sample years. In fact, the universities' decline in efficiency of $5.8 \%$ p.a. is very significant in the context of all colleges experiencing an efficiency improvement of $3.4 \%$ p.a. during this period. The sample of universities is comprised of various types of institutions in terms of size, age, ownership and the dominant type of education they provide. The presence of a large number of newly established private institutions that did not experience a significant improvement in productivity as discussed above is perhaps the main reason for the relatively inferior performance of universities compared to colleges.

Table 4 also contains productivity estimates and components stratified by the age of the institutions, i.e. 'old' meaning equal to or more than 20 years since their establishment, and 'new' meaning less than 20 years. Interestingly, the improvement in productivity could be only linked to older institutions. For the relatively newer institutions, the growth in productivity was in fact zero, but nonetheless not negative. Any improvement/decline in efficiency was offset by an almost equal decline/improvement in production technology for the newer, relatively smaller institutions. For the older institutions, however, the highest technological progress contributed towards a significant improvement in productivity (12.6\% p.a.). Improved efficiency also contributed for some years (three out of the six years). Hence, older and established institutions did catch up with an upward shift in the production frontier as is evidenced by a $10.3 \%$ technological progress compared to a $2.7 \%$ p.a. improvement in efficiency.

A number of factors could have led to the above mentioned trends in productivity. Some of these are mentioned and discussed below. Since the start of the century, HEIs in Saudi Arabia have started facing competition on internal and external fronts. Larger publicly owned institutions have started competing with internally reputed institutions from the Western world and Chinese/Asian institutions on getting high-class publications and thus improving the institutions' visibility. We discuss these visibilityenhancing strategies of the established publicly owned universities and related outcomes in greater detail in another subsection of the paper. More resources have been allocated to getting the technology updated (computers, software, and other research infrastructure). Hence, the increase in productivity for the publicly owned HEIs is followed by technological changes. A significant number of these older universities have medical and health science colleges and a significant changes in technology of these institutions, as noted in Table 4, helped improve the productivity of these institutions. On the other hand, 
private universities who lagged behind established public sector institutions in terms of the number of publications have to expend more resources (financial and human) to satisfy the regulator who started the new accreditation process, and research output and completion of degrees by students on time are two of the significant quality standards among a number of standards to satisfy. Colleges (vocational and health sciences), on the other hand, have improved their productivity by both focusing on efficient use of existing human resources and catching the frontier technology to meet government targets of producing more technically equipped graduates and fulfilling the vacancies becoming available due to the Saudization scheme.

Publicly owned general education providers on the other hand experienced a decline in efficiency almost throughout the entire sample period. Had it not been a significant technological progress and attached medical colleges' progress in terms of mostly both sources contributing positively toward productivity change, these institutions would have documented a significant productivity decline. Similarly, for colleges (health science and technical/vocational colleges), the improvement in productivity has been a combination of improved efficiency in some cases and positive technical change in others. Hence, no obvious pattern exists, but for the universities, clearly, it was technological improvement which contributed to the productivity growth for these institutions. For the newer institutions (both public and private), again improvement in productivity has been a combination of technological advancement in a few sample years and a positive change in efficiency in other years. These institutions again could have fewer colleges (in most cases they either did not have health science colleges or were newly established) and hence were not able to consistently achieve productivity improvements. It appears that welldiversified older institutions have done well due to the better human and financial resources available. In addition, publications in areas other than health and natural sciences are relatively difficult in this part of the world, as has been noticed lately where Asian institutions have not done as well in producing quality research output as Western world institutions.

In an effort to better understand and explain the changes in productivity and its components, we estimated productivity for each output separately rather than joint production of both graduates and publications. The Table 5 below contains the productivity estimates and their sources. Interestingly, on average, Saudi HEIs did not experience any productivity improvement in producing graduates. An analysis across the years indicates that any technology improvement was met with an almost equal decline in efficiency. Publicly owned institutions in fact experience a productivity decline of $3.3 \%$ per annum, mostly coming from technological regress, against a $2.2 \%$ productivity increase for the privately owned HEIs, thanks to technological advancements. These trends are, to some extent, understandable due to the rigidity in promotions of faculty members to higher academic ranks and cost competitiveness and minimization. For 
the private institutions who are relatively new, profit motivation would compel them to play safely and try to maximize revenues by recruiting and graduating more students. These institutions, despite pressure from the Saudi Ministry of Education to publish more, had faced an uphill task in maintaining a higher research budget and allocation of contracted hours to faculty members for research-related activities. The number of publications by these institutions are no match for the volume produced by the publicly owned institutions. This is reflected in the research productivity improvement of roughly $10 \%$ over the sample period compared to $0.9 \%$ for the privately owned institutions. Interestingly, for the publicly owned HEIs, improved research productivity was a consequence of technological improvements. For the privately owned institutions, any improvement in efficiency was matched by technological regress over different sample years (a mirror image situation of the publicly owned HEIs for teaching productivity as discussed above). The impressive research productivity gains of the publicly owned institutions are perhaps justified due to the huge research budget and financial incentives on offer to star researchers during our sample period. In contrast to the financial incentives and professional satisfaction and promotion attached to publishing, penalties for not recruiting a higher number of students and producing graduates in these publicly owned institutions are non-existent.

Table 5: HEIs' separate productivity estimates of graduates' and publications

\begin{tabular}{|c|c|c|c|c|c|c|c|}
\hline & 2009 & 2010 & 2011 & 2012 & 2013 & 2014 & overall \\
\hline \multicolumn{8}{|c|}{ Graduates' productivity estimates } \\
\hline \multicolumn{8}{|c|}{ Overall } \\
\hline efficiency change & 0.989 & 0.986 & 1.077 & 0.946 & 1.051 & 0.959 & 1.001 \\
\hline technical change & 1.120 & 0.986 & 0.967 & 0.997 & 0.961 & 1.032 & 1.006 \\
\hline \multirow[t]{2}{*}{ productivity change } & 1.108 & 0.972 & 1.042 & 0.944 & 1.010 & 0.990 & 1.007 \\
\hline & \multicolumn{7}{|c|}{ publicly owned institutions } \\
\hline efficiency change & 0.989 & 0.996 & 0.951 & 0.995 & 1.045 & 0.998 & 0.996 \\
\hline technical change & 1.145 & 1.034 & 1.091 & 1.007 & 1.045 & 0.949 & 1.037 \\
\hline \multirow[t]{2}{*}{ productivity change } & 1.132 & 1.029 & 1.038 & 1.002 & 1.092 & 0.947 & 1.033 \\
\hline & \multicolumn{7}{|c|}{ privately owned institutions } \\
\hline efficiency change & 0.990 & 0.975 & 1.245 & 0.894 & 1.058 & 0.914 & 1.007 \\
\hline technical change & 1.094 & 0.927 & 0.841 & 0.986 & 0.872 & 1.144 & 0.971 \\
\hline productivity change & 1.084 & 0.904 & 1.047 & 0.882 & 0.923 & 1.046 & 0.978 \\
\hline \multicolumn{8}{|c|}{ Publication productivity estimates } \\
\hline \multicolumn{8}{|c|}{ Overall } \\
\hline efficiency change & 0.993 & 0.914 & 1.019 & 0.967 & 1.027 & 0.973 & 0.984 \\
\hline technical change & 0.941 & 0.972 & 0.926 & 0.970 & 0.961 & 0.980 & 0.959 \\
\hline \multirow[t]{2}{*}{ productivity change } & 0.935 & 0.889 & 0.944 & 0.939 & 0.987 & 0.954 & 0.944 \\
\hline & \multicolumn{7}{|c|}{ publicly owned institutions } \\
\hline efficiency change & 1.046 & 0.977 & 1.007 & 0.984 & 1.006 & 0.999 & 1.003 \\
\hline technical change & 0.908 & 0.888 & 0.848 & 0.912 & 0.935 & 0.926 & 0.904 \\
\hline \multirow[t]{2}{*}{ productivity change } & 0.950 & 0.867 & 0.854 & 0.897 & 0.940 & 0.925 & 0.907 \\
\hline & \multicolumn{7}{|c|}{ privately owned institutions } \\
\hline efficiency change & 0.927 & 0.840 & 1.034 & 0.949 & 1.052 & 0.944 & 0.962 \\
\hline technical change & 0.987 & 1.093 & 1.031 & 1.040 & 0.993 & 1.046 & 1.029 \\
\hline productivity change & 0.915 & 0.918 & 1.066 & 0.987 & 1.045 & 0.988 & 0.991 \\
\hline
\end{tabular}


The faculty members belonging to the publicly owned institutions on average are better trained in research due to $\mathrm{PhDs}$ from Western world universities and more time allocated to research-related activities due to relatively fewer financial constraints resulting in fewer teaching hours. In addition, strict promotion rules in the Kingdom would force these public sector faculty members to publish more to get promoted to higher ranks. These faculty members would have a greater chance of opting for shorter duration contracts to work in the privately owned institutions at comparatively higher wages. Hence, the estimates contained in Table 4 could be better explained with the help of estimation of productivity estimates and components for each output separately, and it appears that each institution opted for the optimum route in line with economics and human behaviour theories.

In the above exercise of estimating productivity and its components, we pooled different types of HEIs that are likely to produce non-homogeneous output in particular graduates. For example, those institutions that impart medical/health science education are different and pooling them with general education provider institutions and building a common frontier production technology could potentially lead to less robust productivity estimates. Something similar could be said of technical and vocational institutions/colleges, which have been set up to produce a future generation of technical graduates and are under less pressure to produce high-quality publications. As a robustness check of our productivity estimates, we divided our sample HEIs into two groups: those providing general education and those involved in producing health sciences and medical graduates and technical and vocational education provider institutions. We aimed to estimate productivity separately for technical and vocational colleges and medical education providers too, but due to very few producing units in separate categories, we were unable to do so. The outcome of the above-mentioned exercise is presented in Table 6 and a summary of the findings is presented below.

Starting with Saudi HEIs' productivity estimates excluding medical and technical colleges, qualitatively, the magnitude of the estimates varies marginally but the findings appear to be similar to the common frontier. Compared to $3 \%$ productivity growth with a pooled sample of all institutions, sample separation results in $2 \%$ productivity growth but again the main contributor appears to be technological progress and compensated for a decline in efficiency. Broadly speaking, yearly trends are similar to the common frontier estimates presented in Table 4. Similar conclusions could be drawn regarding the health science and technical education provider institutions. These institutions experienced an impressive productivity growth of $8 \%$ per annum over the sample period and this number compares well with the average productivity growth comprising $5 \%$ and $12 \%$ presented in Table 4 . More importantly, the contribution of technical change and efficiency change toward productivity improvement/decline appears to be similar across different years of the sample period. The disaggregation of the sample into publicly and privately 
owned institutions produced similar trends over the sample periods as well as the averages. Broadly speaking, these estimates and related discussions provide confidence in presenting and interpreting our main findings from, and subsequent conclusions regarding the study. Hence, for the subsequent regression analysis, we focus on productivity estimates using pooled institutions in finding the drivers of productivity and its related sources.

Table 6: HEIs' separate productivity estimates of types of education provider

\begin{tabular}{|c|c|c|c|c|c|c|c|}
\hline & 2009 & 2010 & 2011 & 2012 & 2013 & 2014 & overall \\
\hline \multicolumn{8}{|c|}{ general education provider institutions } \\
\hline efficiency change & 1.052 & 0.972 & 0.956 & 1.102 & 1.028 & 0.961 & 1.011 \\
\hline technical change & 1.022 & 0.954 & 1.010 & 0.868 & 0.996 & 1.005 & 0.973 \\
\hline \multirow[t]{2}{*}{ productivity change } & 1.075 & 0.927 & 0.966 & 0.956 & 1.024 & 0.965 & 0.983 \\
\hline & \multicolumn{7}{|c|}{ medical and technical education provider institutions } \\
\hline efficiency change & 0.927 & 1.271 & 1.497 & 0.832 & 0.994 & 1.023 & 1.052 \\
\hline technical change & 1.024 & 0.681 & 0.622 & 1.091 & 0.884 & 0.972 & 0.881 \\
\hline productivity change & 0.949 & 0.865 & 0.931 & 0.908 & 0.879 & 0.994 & 0.927 \\
\hline
\end{tabular}

In a nutshell, it is clear from the above analysis and discussion that public sector universities have managed to achieve significant TC leading to an overall productivity growth due mainly to research activity despite experiencing a significant decline in efficiency which was due to much the same activity. Private institutions on the other hand, did the opposite. Their significant improvement in TC was due to teaching (producing graduates) rather than research activity, and their efficiency decline attributed to significant inefficiencies in teaching too. Hence, it appears that a significant investment in technology upgrades, infrastructure and process were made as per the perceived strength of these institutions (research for larger and established publically owned and teaching for relatively new and smaller privately owned institutions). Broadly speaking, these institutions are in fact classified as research focused (public) and teaching focused (private) institutions in the national press. Our findings in terms of technological progress at the cost of decline in efficiency for the established publically owned Saudi higher educational institutions is in fact similar to Johnes (2008) who documented this phenomena in the case study of the English higher education sector subsequent to rapid changes in the industry, comprising of more students intake and increased use of technology, amongst many others. The authors concluded that an increasing use of e-learning and information technology could have helped achieving positive technical change but then the increasing number of students intake due to technology and the government objective of increasing participation in higher education sector could have led to less time available to faculty members to perform research.

The increased investment in research related infrastructure by the Saudi established publically owned higher educational institutions is not a new strategy, as many institutions across the world did so to 
improve their ranking in particular. Stoica (2016) amongst many others, concluded similar for the Romanian universities during early 2000s. The increase in research productivity leading to overall productivity for Saudi publically owned institutions due to better research infrastructure, is also comparable to institutions in advanced economies who have a better and well established research infrastructure. The study by Guccio et al. (2016) reported an increase in efficiency, mainly due to an increase in research related activities for Italian higher educational institutions. The increase in teaching efficiency was limited to only a very few years of the sample period and then subsequently declined. The study attributed to an increase in Italian universities research efficiencies to the funding model which rewarded HEIs' research performance. The Saudi funding model for the public sector universities is although not entirely dependent on research performance but those institutions with better research performance indeed enjoy more prestige which results in concessions from the Ministry of Education tighter controls as well as better chances of collaborative research arrangements with western institutions due to improved global ranking and visibility.

The overall conclusion from the estimates contained in the above tables and related analysis seems to be that the Kingdom's higher education institutions did experience an improvement in productivity but there is a great deal of heterogeneity among different types of institutions in terms of age, the education they impart, ownership and size etc. We hope to cover this heterogeneity in the following subsection by performing a regression analysis to control for initial conditions (labour market and macroeconomic environment) and other factors.

\section{Determinants of productivity change and its components}

Table 7 contains findings of the regressing of a number of institution-specific and macroeconomic/labour market condition variables on total factor productivity and its determinants (efficiency and technological change) using panel data random effect model. Starting with the age of the institutions and controlling for other factors, estimates reveal that older institutions (predominantly publicly owned) are more likely to be more productive and achieve technological progress than newly established HEIs. The new institutions are although more flexible in using technology and e-learning tools and thus can manage to make better technological progress. However, the older publicly owned institutions' better performance is not surprising given the fact that newer institutions (predominantly private), despite being less burdened by excessively large workforces (faculty members as well as administrators), which in some cases are used as an employment generation tool by the government, lack the physical and financial resources to invest in technologies to improve the learning of their students as well as advanced training of faculty members in performing and disseminating research. The experience gained over many decades helps these older institutions to do better in producing more research output in particular as discussed before. 
On the other hand, if older institutions happened to be less likely to be more productive, then this would have a strong bearing in terms of 'value for money' due to the fact that these institutions have a budget worth billions of dollars. These institutions have been spending billions on research-related activities in particular and have access to human and financial resources not matched by the private sector institutions, which in most cases are solely dependent on tuition income (as research income contributions are negligible for these institutions). Hence, the finding that older institutions, which are predominantly larger public sector institutions, are more likely to be more productive than newer (mostly private) institutions is something that is encouraging in the context of value for money principle. These institutions are also significant recipients of the Saudization intake (for both faculty members and administrative staff) and this finding after controlling for other factors in particular indicates that they have not suffered in terms of production loss from replacing foreign faculty members with local ones as a result of government policy change and resulting trends in economic and employment dynamics.

Compared to the findings reported in Table 4, whether an institution is a university or a college, or a general or medical education provider, all these have no statistically significant impact on productivity and its components. One of the possible reason could be that age of the institution and two other institution specific variables which we discuss next could have absorbed the impact of this variable in our regression model. As expected, two institution specific interesting ratios, i.e. the ratios of graduates produced/total faculty members and total publications/administrative staff, positively impact on productivity, efficiency and technical change. The publications/administrative staff ratio, however, does not impact on TC. These two variables to some extent can also be considered controlling factors of the size of the institutions in our case. Bigger publically owned institutions in particular are expected to have higher values for these two variables as they are bigger and produce more graduates and publications. This perhaps should make them more productive and efficient, and after controlling for other factors, this does appear to be the case. It appears that for the first ratio, both technical change and efficiency are positively impacted, but for the second ratio, only change in efficiency is positively influenced. The presence of more support staff perhaps helps faculty members to collect data, and perform lab experiments efficiently. Increasing the ratio of students to staff may have an adverse effect on performance (e.g. student achievement rates and research levels may be affected (Jones, 2008)), but this does not seem to be happening in our case as loss of time due to teaching could have been compensated by higher research budget allocations and resulting acquiring of advance technology for the publically owned institutions in particular. The increase in the ratio of graduates produced/faculty members may also indicate a higher class size leading to problems of technology upgrades that are not done on time due to competing demand to hire and maintain more research active academic faculty members. But nonetheless, generous budget support from the government during the sample period avoided such a 
problem. Hence, it is not just having a higher students to staff ratio that could be a big problem, but producing efficiently by adopting newer learning technologies and techniques is more important for matching frontier technology adopter institutions. The older public sector institutions, with billions of dollars' worth of finance provided by the government, appear to be doing exactly what is mentioned above during our sample period.

The next set of variables are related to overall economic activity and prevailing labour market conditions. Starting with macroeconomic determinants, the estimates reveal that higher credit disbursement to the private sector influences TC negatively but efficiency positively. In theory, we would have expected that an increase in domestic credit supply by financial institutions such as banks would help HEIs to borrow more to finance an upgrade of the technology and help improve the production process to catch an efficient frontier. But the Kingdom has a special situation and this could have led to our findings. Firstly, the majority of the publicly owned higher educational institutions are totally dependent on government finances and hence are less influenced by the private credit market dynamics. Secondly, even those institutions owned by the private sector have other financing options, such as family equity finance and inter-business financing, as these educational institutions are part of a larger conglomerate of business entities. Thirdly, the increase in credit to the private sector during our sample period has not been channelled to the educational institutions in particular. The following Figure 1 contains growth rates of the share of financial institution credit to the different components of the private and government sector. It is clear from these figures that increased financing has been limited to only a few sectors, such as energy, private health sector, finance, building and construction, and mining and manufacturing, in particular. Interestingly, the miscellaneous category, which perhaps contains the educational sector credit supply share alongside many other sectors, recorded the lowest growth in credit disbursement share during our sample period.

Figure 1: Growth rates of the share of financial institution credit to different sectors 


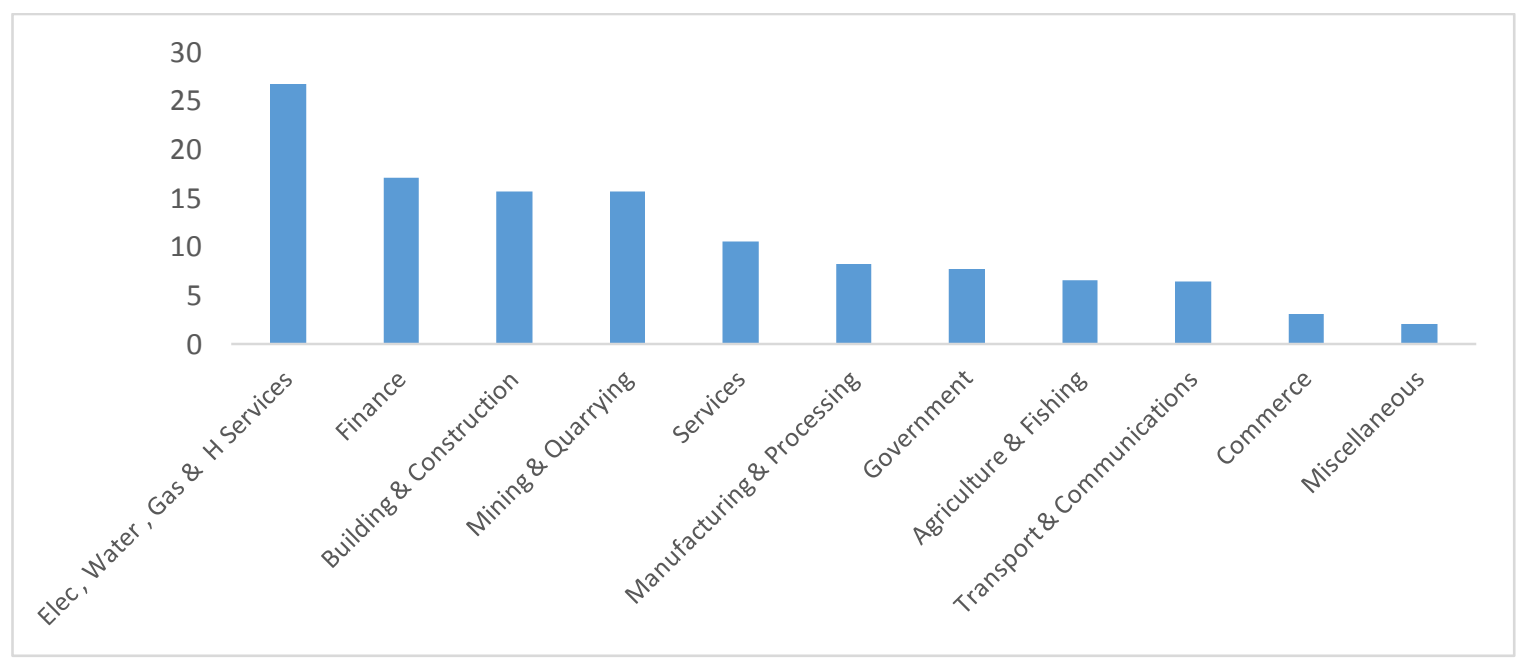

A higher domestic credit allocation to other sectors however could lead to higher liquidity being available through the banking system, leading to higher employment generation due to growth in government and private sector contracts, resulting in students being more able to afford to join higher education. More resources for HEIs, in particularly privately-owned institutions, would lead to more investment in teaching and research technology upgrades and adoption and hence better use of existing resources alongside the achievement of economies of scale due to increasing intake of students. This would eventually lead to improved efficiency. The empirical evidence on the existence of economies of scale in higher educational sector is however debatable. Some of the interesting studies in this context are Cohn et al. (1989), Felderer and Obersteiner (1999) and Bonaccorsi et al. (2006). The study by Selim and Bursalioglu (2013) on the Turkish universities concluded a positive relationship between the number of students per academic and the relative efficiency of universities. It was the same for the number of publications too. Zhang et al. (2017) also found clear evidence of economies of scale for the Australian universities when investigating the role of increasing intake of international students and joint production of international graduates alongside local students.

The estimates show that, similarly to expectation, rising per capital income and higher capital formation impact positively on TC. More investment by both government and private sector and better economic prospects encourage institutions to improve technological resources and catch up with frontier technology. The negative impact of ease of doing business measured by the number of days it takes to start a business on TC is as expected and the coefficient is statistically significant too. A higher number of days required to start a business could perhaps be a discouraging factor in relation to investing in technology upgrades due to issues in securing finances and other government agencies' approval. A higher number of days is also an indicator of business climate and a proxy for the ease of doing business 
in the country. More bureaucratic red-tapism discourages innovation as well competition in the industry which are important determinants of the technological advances and efficiencies in operations.

As discussed in the methodology section, rather than using macroeconomic condition variables that could indirectly affect HEIs' total productivity and its components, next we use labour market condition variables, which could directly influence educational institution productivity and its sources. We did not include both labour market and macroeconomic variables together in the regression due to the potential high co-linearity among these variables. In relation to labour market conditions impacting on productivity and its components, three variables in particular are very relevant and important in this regard and used in our regression framework. The estimates contained in Table 7 show that the employment to population ratio and lower secondary completion rate both have a positive impact on TC. A higher employment ratio and increasing lower secondary completion rates could be the result of better economic conditions. An increasing lower secondary completion and better job prospects would result in higher intake of students leading to higher economies of scale and more financial resources available to make investment in technology upgrades. Interestingly, easing economic conditions represented by GDP per capita growth would also have a similar positive impact on TC. These findings appear to indicate that better economic and labour market conditions generate a feel-good factor alongside job security and more employment prospects in both the public and private sector and this may result in greater efforts by both faculty members and administrative staff alongside higher investment in acquiring of new technologies.

Similar conclusions for the technical change cannot be drawn for the proportion of female faculty members in tertiary education and the percentage of students in secondary general education who are female. Interestingly, in the context of European countries, a study by Wolszczak-Derlacz and Parteka (2011) concluded the opposite stating that higher proportion of female faculty members among academic staff improves efficiencies of the higher educational institutions. Hence, a big push to induct female Saudis into employment in particular as ready-made replacements for expatriates to meet Saudization targets appears not to be leading to more desire or ability on the part of management to adopt new technologies and use human and physical resources more efficiently or reduce the input quantities by adopting new technologies. This finding supplements the generally accepted viewpoint of low productivity of the female Saudi labour force in the country due to cultural and religious constraints. Another plausible explanation could be the prevailing news stories in relation to female employment in private sector in particular. There have been stories going round in the national press that some organizations have cheated the system by just showing female Saudis on their payroll to meet Saudization benchmarks and to avoid resulting financial penalties if these numbers are missed. In fact, this is the area 
where policymakers have to be more vigilant during economic recession periods in implementing employment policies in general and female participation in particular. 
Table 7: Determinants of Saudi's HEls productivity and its components estimates

Institution is university

Institution is publically owned

Institution is general education provider

Institution is medical education provider

Institution is old

Ratio of graduates produced/faculty

Ratio of publications/administrative staff

Employment to population ratio, 15+, total (\%) (national estimate)

Lower secondary completion rate, total (\% of relevant age group)

Percentage of students in secondary general education who are female (\%)

Tertiary education, academic staff (\% female)

GDP per capita growth (annual \%)

Domestic credit to private sector (\% of GDP)

Gross capital formation (\% of GDP)

Time required to start a business (days)

Constant

\begin{tabular}{cc}
\multicolumn{2}{c}{ Productivity change } \\
\hline-0.0221 & -0.0251 \\
0.0504 & 0.0535 \\
0.1145 & 0.1077 \\
0.0759 & 0.0714 \\
$-0.1687^{* * *}$ & $-0.1741^{* * *}$ \\
$-0.0325^{* * *}$ & $-0.0317^{* * *}$ \\
$-0.1704^{* *}$ & $-0.1602^{* *}$ \\
& -0.0114 \\
& -0.0296 \\
& 0.0465 \\
& 0.0465 \\
-0.0134 & 0.0003 \\
0.0005 & \\
-0.0166 & \\
0.0319 & \\
0.8132 & 0.5352
\end{tabular}

319

Observations

319

61

Notes: $* * * p<0.01, * * \mathrm{p}<0.05, * \mathrm{p}<0.1$
Efficiency change

0.0234

0.0289

0.0289
0.1622

0.1344

$-0.0933$

$-0.0284 * *$

$-0.1649 *$

Technical change

0.0217

0.0306

0.1584

0.1319

$-0.0964$

$-0.0279 * *$

$-0.1590^{*}$

0.2031

0.0391

$-0.3403$

$-0.4476$

$-0.0152-0.0607$

$-0.0335 * *$

0.0484

$-0.0440$

$2.0469 * * *$

19.9212

319

61

61 $\begin{array}{ll}-0.0539 & -0.0559\end{array}$

$0.0097 \quad 0.0114$

$-0.0160 \quad-0.0182$

$-0.0284 \quad-0.0296$

$-0.0822 * * \quad-0.0849 * *$

$-0.0087^{*}-0.0083^{*}$

$-0.0251 \quad-0.0187$

$-0.1872 * * *$

$0.3225 * *$

$0.4149 * * *$

$0.0050 \quad-0.0458$

$0.0287 * * *$

$-0.0527 * * *$

$0.0679 * * *$

$-0.1627$

$-14.6830 *$

$\begin{array}{rr}319 & 319 \\ 61 & 61\end{array}$

61 
Given the importance and weight of government-owned bigger, prestigious and older institutions in the Saudi Arabian higher education system, we ran another set of regressions by utilizing panel data random effect model, whereby we interacted public ownership with macroeconomic and labour market condition variables to further investigate the role of public sector ownership of HEIs in particular. The outcome of this exercise is shown in Table 8. Similarly to the previous results, the age of the institution significantly influences TC and a positive relationship is established, but interestingly, public ownership is negatively associated with efficiency change in the labour market condition variable and positively with TC. This is not unexpected as discussed earlier due to female employment and related issues alongside inefficiencies in producing research output. It is vice versa in the case of a regression model where the indirect effect is approximated by the macroeconomic conditions which perhaps include many other indirect effects. Hence, the inclusion of interaction terms alters the sign and statistical significance of the coefficients. The findings of the both models (with and without labor market conditions) are interesting nonetheless. Similarly, the ratio of graduates produced/total academic faculty members and publications/administrative staff both significantly and positively influences EC but not TC. Higher publications alongside more graduates productions could bring cost complementarities nonetheless. The impact of economies of scale could be another important reason for this finding.

Looking at the impact of macroeconomic variables, domestic credit to the private sector impacts positively on efficiency but negatively on TC for private institutions only and no such effects on government-owned institutions are found. We have already provided explanation in this regard. In addition, higher credit to the private sector could indirectly indicate better economic conditions and a greater student intake for these institutions, leading to operating on the optimal scale (leading to an increase in efficiency). On the other hand, as discussed before, the growth of credit to private sector educational institutions in particular has been low as discussed before. Government-owned institutions, on the other hand, are not dependent on external finances. EC is impacted negatively by gross capital formation for private institutions but the same impacts positively on TC in the case of both privately and government-owned HEIs. Higher investment by the government sector perhaps happens during better economic conditions and opens avenues for the private sector to invest in technology upgrades as they would find it hard to replace staff with rising employment levels due to relatively lower wages in the education sector. Higher capital formation also means more government contracts and greater student recruitment for private institutions leading to more money for these institutions. Easy macroeconomic conditions again impact positively on technical progress for both types of institution.

On the other hand, GDP per capita impacts positively on TC only for government-owned HEIs. Rising income levels probably make it easier to admit students and thus this works as an incentive for these 
institutions. The government could also spend more money in government institutions on technology and the development of human resources during periods of rising income levels. Rising income levels translate into a higher number of students for institutions leading to economies of scale, and this could lead to more investment in technology upgrades and research infrastructure for these institutions. But the fact that this impact on private institutions is not positive is surprising. Again the negative impact of ease of doing business measured by the number of days it takes to start a business on TC is as expected for both types of institution and, as discussed above, a higher number of days required to start a business could perhaps be linked to issues in regard to obtaining finances and approval from a number of government agencies. The positive impact on efficiency change for private institutions is as expected as these institutions are better equipped to deal with delays and could compensate themselves by improving operations, leading to operational efficiencies.

Next, we look at the interactions in relation to labour market conditions. The estimates contained in Table 8 indicate that the increase in lower secondary completion rate impacts negatively on EC for private institutions only but positively on TC for both types of institution. A higher completion rate means more students and private institutions may not go for improving efficiency due to easy money or may find it hard to operate efficiently due to pressure on limited human and technological resources. On the other hand, it does push both types of institution to invest in new technology and other learning tools to meet requirements and to compete against frontier institutions to gain better use of technology from a higher supply of students. The increase in the number of female students in secondary education impacts negatively on TC for government-run institutions only and no such statistically significant impact is observed for privately run institutions. Most of these female students will eventually end up joining publicly owned institutions, thereby creating pressure on human and technological resources and less scope for learning technology upgrades. The increased numbers mean less funds available per student from the government and thus less investment by the management in improving learning through new technologies.

Similarly, increasing the ratio of female faculty members in tertiary education brings a negative change in TC for both types of higher education institutions. A higher female participation rate in tertiary education could lead to a huge amount of money being spent on perks and benefits to ensure the retention of the female workforce in the educational sector. The government has set some thresholds in terms of a certain percentage of Saudi female members as discussed before and HEIs are obliged to make the learning process smooth if there is to be any chance of retaining a good number of female faculty members in the institutions. 


\begin{tabular}{|c|c|c|c|c|}
\hline & \multicolumn{2}{|c|}{ Macroeconomic conditions } & \multicolumn{2}{|c|}{ Labour market conditions } \\
\hline & Efficiency change & Technical change & Efficiency change & Technical change \\
\hline Institution is university & 0.0331 & -0.0557 & 0.0320 & -0.0588 \\
\hline Institution is publically owned & $-3.7719 * * *$ & $2.3141 * * *$ & $29.0749 * * *$ & $-20.3915 * * *$ \\
\hline Institution is general education provider & 0.1929 & -0.0281 & 0.1867 & -0.0292 \\
\hline Institution is medical education provider & 0.1691 & -0.0399 & 0.1611 & -0.0388 \\
\hline Institution is old & -0.0904 & $-0.0844 * * *$ & -0.0949 & $-0.0862 * * *$ \\
\hline Ratio of graduates produced/faculty & $-0.0303 * * *$ & -0.0064 & $-0.0316 * * *$ & -0.0053 \\
\hline Ratio of publications/administrative staff & $-0.1655^{*}$ & -0.0227 & $-0.1625^{*}$ & -0.0138 \\
\hline Domestic credit to private sector (\% of GDP) & $-0.0766^{* * *}$ & $0.0594 * * *$ & & \\
\hline GDP per capita growth (annual \%) & -0.0168 & $0.0355^{* * *}$ & & \\
\hline Gross capital formation (\% of GDP) & $0.1042 * *$ & $-0.0739 * * *$ & & \\
\hline Time required to start a business (days) & $-0.1271 * *$ & $0.0913^{* * *}$ & & \\
\hline \multicolumn{5}{|l|}{ Interactions with publically owned institution } \\
\hline Domestic credit to private sector (\% of GDP)*public & $0.0812 * * *$ & $-0.0576 * * *$ & & \\
\hline GDP per capita growth (annual \%)*public & 0.0031 & $-0.0566 * * *$ & & \\
\hline Gross capital formation (\% of GDP)*public & $-0.1061 *$ & $0.0418 *$ & & \\
\hline Time required to start a business (days)*public & $0.1562 *$ & -0.0463 & & \\
\hline Domestic credit to private sector (\% of GDP) & 0.0046 & 0.0018 & & \\
\hline GDP per capita growth (annual \%) & -0.0137 & $-0.0212 * *$ & & \\
\hline Gross capital formation ( $\%$ of GDP) & -0.0020 & $-0.0321 * *$ & & \\
\hline Time required to start a business (days) & 0.0291 & $0.0450 * *$ & & \\
\hline Employment to population ratio, $15+$, total (\%) (national estimate) & & & 0.1967 & $-0.1798 * * *$ \\
\hline Lower secondary completion rate, total (\% of relevant age group) & & & $0.0653 *$ & $-0.0744 * * *$ \\
\hline Percentage of students in secondary general education who are female (\%) & & & -0.1381 & 0.1702 \\
\hline Tertiary education, academic staff ( $\%$ female) & & & -0.3109 & $0.3132 * *$ \\
\hline GDP per capita growth (annual \%) & & & 0.0236 & -0.0023 \\
\hline \multicolumn{5}{|l|}{ Interactions with publically owned institution } \\
\hline Lower secondary completion rate, total ( $\%$ of relevant age group)*public & & & $-0.0481 *$ & $0.0305 * * *$ \\
\hline Percentage of students in secondary general education who are female $(\%)^{*}$ public & & & $-0.3449 * *$ & $0.2517 * * *$ \\
\hline Tertiary education, academic staff ( $\%$ female) $*$ public & & & $-0.2205^{*}$ & $0.1537 * * *$ \\
\hline GDP per capita growth (annual \%)*public & & & 0.0622 & $-0.0751 * * *$ \\
\hline \multicolumn{5}{|l|}{ Recalculated coefficient for publically owned institutions (sum of coefficients) } \\
\hline Lower secondary completion rate, total (\% of relevant age group) & & & 0.0172 & $-0.0440 * * *$ \\
\hline Percentage of students in secondary general education who are female (\%) & & & -0.4830 & $0.4219 * * *$ \\
\hline
\end{tabular}




\section{Broader Contributions of Saudi Higher Educational Institutions toward Economy and Society}

Beyond the issue of how efficiently higher educational institutions are producing graduates and research papers which was the main thrust of this study, the broader role of higher educational institutions in transforming the economy and society is also extremely significant and important. Saudi universities have not only started encouraging women's participation in higher education but leadership opportunities have also been created in Saudi HEIs in particular for this relatively less represented segment of the society. Princess Nora Bint Abdul Rahman University has appointed the first female as the head of the institution. This institution is also staffed entirely by women academics and administrative staff. The statistics released by the Saudi Ministry of Education show that there were 12 vice-presidents, 61 deans and 228 deputy deans among women faculty working in the different Saudi higher educational institutions in 2016/17. This, in fact, is a significant development in the context of the historical practices of maledominant academic leadership as well as being in line with the Kingdom's long-term plan to increase women's participation in the workforce from $22 \%$ to $30 \%$ by 2030 . The 28 state universities in Saudi Arabia enrolled 1.3m students in the 2014/15 academic year, including 692,673 women, who represented $53 \%$ of the total student body. Given the gender-based segregated teaching arrangements for male and female students and their impact on diseconomies of scale, this important role in educating women is extremely valuable but perhaps could have been one of the reasons for the deterioration in the efficiency of the institutions as discussed before. More importantly, as discussed before, our sample period coincides with increasing enrolment of female students.

Based on broader key performance indicators of quality in HEIs, the Saudi universities have also started a journey toward competing internationally and being counted among the best, thereby helping improve the visibility of the country on the knowledge front. An in-depth analysis of the Shanghai Ranking reveals that Saudi Arabia was among the four countries, along with China, Australia and Taiwan, that have achieved significant progress with four additional universities being included in the top 500 between 2004 and 2014 (in fact two of them appeared in the top 150 to 200 group). Similarly, according to the assessment of Universitas 21, Saudi Arabia was the only Arab country to be counted among the top 50 higher education systems (ranked 28 in 2015). The QS ranking of the Arab universities in 2016 represents some impressive performances by Saudi universities. Three universities from the Kingdom were among the top ten, two were in the top 20 and 19 were ranked in the top 100 institutions. King Saud University in particular climbed the ladder significantly in this regard. One of the Saudi universities was also ranked among the top 200 in the world between 2012 and 2016 by QS. The Academic Ranking of World Universities (ARWU) also put two Saudi universities among the top 150 world universities. KAUST, a 
relatively younger publicly owned university, is expected to become a scientific powerhouse in the nottoo-distant future.

Saudi universities have also started playing a greater role in sustainable economic growth and development. Similarly to other resource-rich economies, Saudi Arabia is keen to diversify its economic base by producing and exporting non-oil products and services. The contribution of the Saudi higher educational sector toward the national economy in terms of a producer of human capital and employment generation is substantial irrespective of how efficiently these two outputs are produced. There were roughly 74,000 academics working in the higher education sector in 2014, increasing from roughly 33,000 back in 2008. This more than twofold increase in the numbers within a short period of time is significant in the context of rising unemployment among the Saudi young educated class even if half of these were Saudis. The increase in the non-academic workforce has been even higher; in fact, the number went up threefold from 24,000 to 72,000 during the period 2008 to 2014 and a significant proportion of these employed in the higher education sector are likely to be Saudis. The combined employment figure of 145,948 in 2014 would have contributed substantially to the local and regional economy. At an average monthly salary of SAR 15,000 for academic staff and 2500 (lower end pay scale) for support staff, the total expenditure on salaries would be SAR 15 billion or USD 4 billion. With a marginal propensity to consume of say 0.80 , the contribution toward GDP is likely to be significant. Similarly, these institutions produced roughly 0.9 million graduates (mostly Saudis) during the sample period, which would contribute toward pushing the Kingdom to the next level in terms of economic activity and progress in years to come and bodes well for the success of Vision 2030.

\section{Conclusions}

This study looks into the productive performance of Saudi higher education institutions over a six-year period. This period witnessed a significant increase in government support for the sector through scholarships for students and generous research and infrastructure development grants. In contrast to the widely used techniques that suffer from a number of shortcomings, the estimation of total factor productivity is performed by using an advanced non-parametric estimator that can deal with dimension issues and outliers. The productivity estimates reveal that due to the huge sum of money invested by the government and the emerging role of the private sector in the higher education sector since 2008 in particular, productivity has improved over time (roughly $3 \%$ p.a.). This improvement has been due to technological progress and despite a significant decline in efficiency. This positive change in productivity is true irrespective of ownership type (public/private), type of education (general/vocational or medical) and level of education (college/university). The magnitude of this improvement, however, differs across

institutions. Interestingly, universities in particular experienced a significant decline in efficiency during 
the sample period. Looking into this in greater depth, it was found that older (predominantly publicly owned) institutions were in fact the main contributors to the sector's productivity improvement when compared to those new institutions that have been set up since the beginning of the century as a result of the opening up of the higher education market to the private sector.

In an effort to further understand the trend in productivity and its components, we regressed these productivity indices alongside components against a set of institution-specific variables as well as the country's labour market and economic conditions. In line with the descriptive statistics of the estimates, the regression exercise confirms that older institutions are more productive and were more likely to progress technologically over the sample period than newer ones. Further, whether an institution is a university or a college, or a general or medical education provider, all these have no statistically significant impact on productivity and its components. Maximizing the number of graduates and publications and looking into efficient input usage is a very productive strategy on the part of management. Maximizing the number of publications appears to improve efficiency, and increasing the supply of graduates also leads to improved efficiency as well as technological progress. Broadly speaking, better labour market and macroeconomic conditions did help institutions to achieve technological progress. Some variables, such as an increase in credit to the private sector, and female participation in the tertiary education labour market, do not help institutions to achieve technical progress. In some cases, the impact of the number of macroeconomic and labour market variables on technological progress and efficiency improvement appears to be different for two different kinds of ownership institution, i.e. those that are publicly owned and those that are privately owned.

\section{Acknowledgements}

We would like to express our appreciation and acknowledge the comments made by the two anonymous referees on earlier version of the paper. The usual disclaimer applies.

\section{References}

Agasisti, T., \& Johnes, J. (2010). Heterogeneity and the Evaluation of Efficiency: The Case of Italian Universities. Applied Economics, 42(11), 1365-75.

Al-Mutairi, K. A., \& Al-Shami, S. A. (2015). Scientific Research in Saudi Universities: Science Thrives in the Desert. Global Journal of Biology, Agriculture and Health Sciences, 4(3), 85-90.

Alshayea, A., Battal, A., \& Jarwaan, S. (2013). Total Productivity Growth in the Faculties of Anbar University using Malmquist Productivity Index. International Journal of Global Education, 2(3).

Aragon, Y., Daouia, A., \& Thomas-Agnan, C. (2005). Nonparametric Frontier Estimation: A Conditional Quantile-Based Approach. Econometric Theory, 21(2), 358-89. 
Athanassopoulos, A. D., \& Shale, E. (1997). Assessing the Comparative Efficiency of Higher Education Institutions in the UK by the Means of Data Envelopment Analysis. Journal Education Economics, 5(2), 117-34.

Aubyn, M. S., Garcia, F., \& Pais, J. (2009). Study on the Efficiency and Effectiveness of Public Spending on Tertiary Education (No. 390). Directorate General Economic and Financial Affairs (DG ECFIN), European Commission.

Bonaccorsi, A., Daraio, C., \& Simar, L. (2006). Advanced Indicators of Productivity of Universities. An Application of Robust Nonparametric Methods to Italian Data. Scientometrics, 66(2), 389-410.

Cazals, C., Florens, J. P., \& Simar, L. (2002). Nonparametric Frontier Estimation: A Robust Approach. Journal of econometrics, 106(1), 1-25.

Clarke, P., Crawford, C., Steele, F., \& Vignoles, A. F. (2010). The Choice between Fixed and Random Effects Models: Some Considerations for Educational Research.

Cohn, E., Rhine, S. L. W., \& Santos, M. C. (1989). Institutions of higher education as multi-product firms: economies of scale and scope. Review of Economics and Statistics, 71, 284-290.

Cunha, M., \& Rocha, V. (2012). On the Efficiency of Public Higher Education Institutions in Portugal: an exploratory study. University of Porto: FEP Working Paper, (468).

Daouia, A. (2003). Nonparametric Analysis of Frontier Production Functions and Efficiency Measurement Using Nonstandard Conditional Quantiles. Unpublished doctoral dissertation). Groupe de Recherche en Economie Mathématique et Quantititative, Université des Sciences Sociales, Toulouse I, et Laboratoire de Statistique et Probabilités, Université Paul Sabatier, Toulouse III, France.

Daouia, A., \& Simar, L. (2007). Nonparametric Efficiency Analysis: A Multivariate Conditional Quantile Approach. Journal of Econometrics, 140(2), 375-400.

Deprins, D., \& Simar, L. (1984). Measuring Labor Efficiency in Post Office (fices. In Marchand M., P. Pestieau and H. Tulkens (eds.), The Performance of Public Enterprises: Concepts and Measurements.

Eckles, J. E. (2010). Evaluating the Efficiency of Top Liberal Arts Colleges. Research in Higher Education, 51(3), 266-93.

Färe, R., Grosskopf, S., \& Knox Lovell, C. A. (1985). The Measurement of Efficiency of Production (Vol. 6). New York: Springer.

Felderer, B., \& Obersteiner, M. (1999). Efficiency and economies of scale in academic knowledge production,Economics Series no. 63, Institute for Advanced Studies, Vienna.

Foltz, J. D., Barham, B. L., Chavas, J. P., \& Kim, K. (2012). Efficiency and technological change at US research universities. Journal of Productivity Analysis, 37(2), 171-186.

Guccio, C., Martorana, M. F., \& Mazza, I. (2016). Efficiency assessment and convergence in teaching and research in Italian public universities. Scientometrics, 107(3), 1063-1094. 
Johnes, J. (2004). Efficiency Measurement, in G. Johnes and J. Johnes (eds), The International Handbook on the Economics of Education, Cheltenham, Edward Elgar.

Johnes, J. (2008). Efficiency and Productivity Change in the English Higher Education Sector from 1996/07 to 2002/03. The Manchester School, 76(6), 653-74.

Johnes, J., \& Li, Y. U. (2008). Measuring the Research Performance of Chinese Higher Education Institutions Using Data Envelopment Analysis. China Economic Review, 19(4), 679-696.

Joumady, O., \& Ris, C. (2005). Performance in European Higher Education: A Non- Parametric Production Frontier Approach. Education Economics, 13(2), 189-205.

Kantabutra, S., \& Tang, J. C. (2010). Efficiency Analysis of Public Universities in Thailand. Tertiary Education and Management, 16(1), 15-33.

Selim, S., \& Bursalioglu, S. A. (2013). Analysis of the determinants of universities efficiency in Turkey: Application of the data envelopment analysis and panel Tobit model. Procedia-Social and Behavioral Sciences, 89, 895-900.

Shepherd, R. (1970). Theory of Cost and Production Functions. New Jersey: Princeton University Press. Stocia, M., \& Aldea, A. (2016). Efficiency of Teaching and Research Activities in Romanian Universities: An Order-Alpha Partial Frontiers Approach. Economic Computation and Economic Cybernetics Studies and Research, 50(4), 169-86.

Wheelock, D. C., \& Wilson, P. W. (2003). Robust Nonparametric Estimation of Efficiency and Technical Change in U.S. Commercial Banking. Working paper series, Working Paper 2003-037A. Federal Reserve Bank of St. Louis.

Wheelock, D. C., \& Wilson, P. W. (2008). Non-Parametric, Unconditional Quantile Estimation for Efficiency Analysis with an Application to Federal Reserve Check Processing Operations. Journal of Econometrics, 145(1-2), 209-25.

Wheelock, D. C., \& Wilson P. W. (2009). Robust Nonparametric Quantile Estimation of Efficiency and Productivity Change in US Commercial Banking. 1985-2004. Journal of Business and Economic Statistics 27(3): 354-68., 27(3), 354-68.

Wilson, P. W. (2008). FEAR: A Software Package for Frontier Efficiency Analysis with R. Socioeconomic planning sciences, 42(4), 247-54.

Wolszczak-Derlacz, J., \& Parteka, A. (2011). Efficiency of European Public Higher Education Institutions: A Two-Stage Multi-country Approach. Scientometrics, 89(3), 887.

Worthington, A. C. (2001). An Empirical Survey of Frontier Efficiency Measurement Techniques in Education, Education Economics, Vol. 9, No. 3, 245-268.

Zhang, L. C., Worthington, A. C., \& Hu, M. (2017). Cost economies in the provision of higher education for international students: Australian evidence. Higher Education, 74(4), 717-734. 
